\title{
DOCUMENTS
}

\section{THE COMMENTARY OF ORIGEN UPON THE EPISTLE TO THE EPHESIANS: PART III.}

THE TEXT: EPH. iv 27-vi 24.

\author{
$\S \mathrm{XX}$.

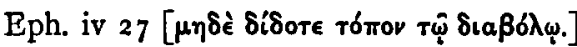

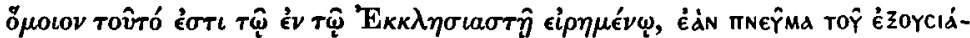

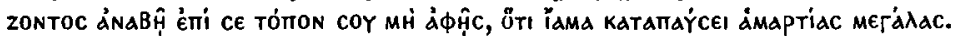

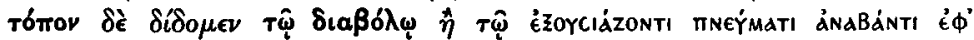

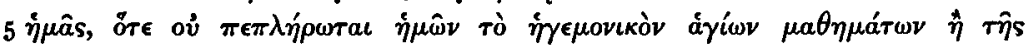

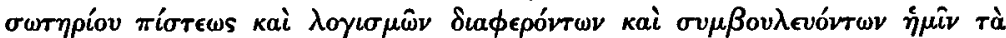

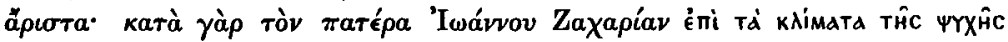

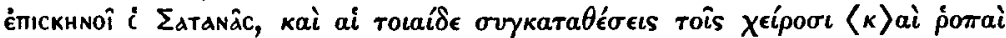

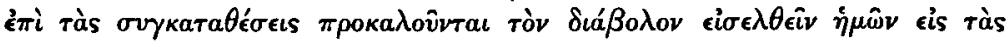

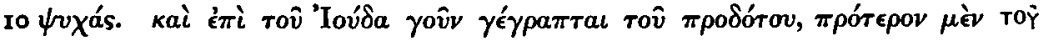

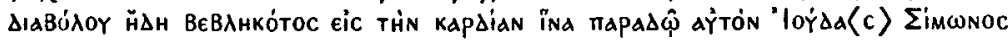

$\mathrm{XX}_{2}, 4$. Eccl, $\mathrm{x}_{4} \quad$ 7. From a lost Zacharias-apocryphon : see lower notes Io. Jo. xiii 2

$$
\mathrm{XX} \mathrm{2,3:630} \mathrm{C} \mathrm{9-15:630} \mathrm{B}
$$

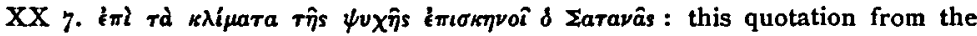
lost apocryphon of 'Zacharias the father of John' is not noticed by Berendts Studien über Zacharias-Apokryphen und Zacharias-Legenden (Leipzig, 1895). That Origen was acquainted, at any rate at the end of his life, with an apocryphal writing dealing with the death of Zacharias father of John-whom he confidently identifies with the Zacharias of Matt. xxiii 35-Berendts shows from the Comm. in Matt seres 2526 (Delarue iii 845 ); nor is the passage earlier in the same commentary, Tom. $x 18$ (Delarue iii 465 ), as difficult to reconcile with such acquaint-

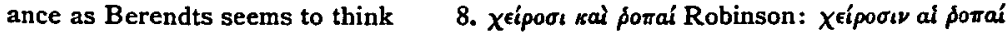
MS II. Iovías: Iovió MS 


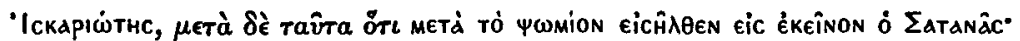

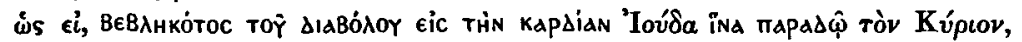

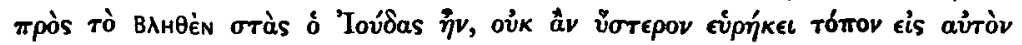

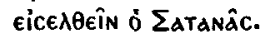

[iv 28 ] $\delta$ k

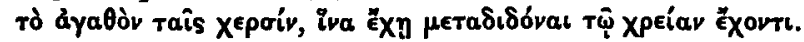

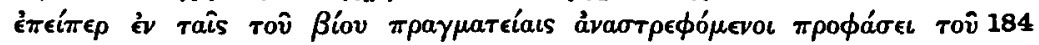

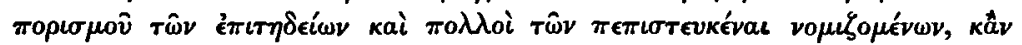

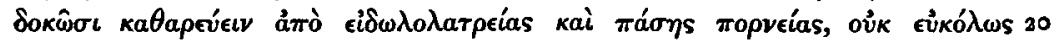

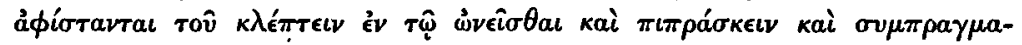

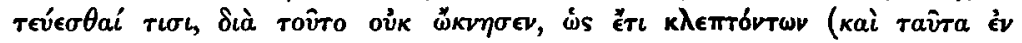

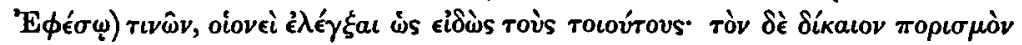

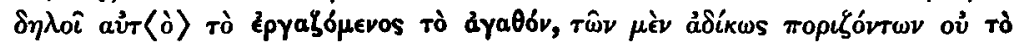

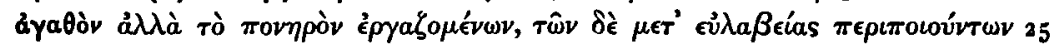

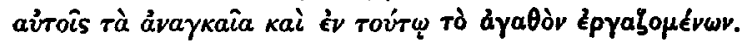

\section{$\S \mathrm{XXI}$.}

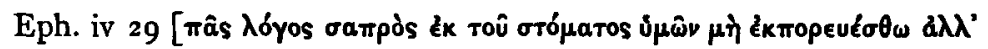

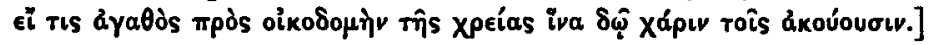

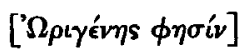

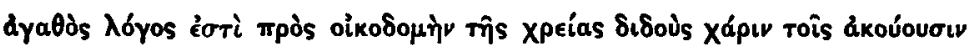

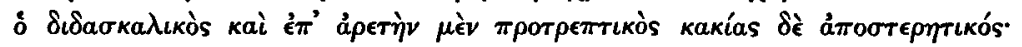

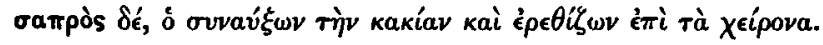

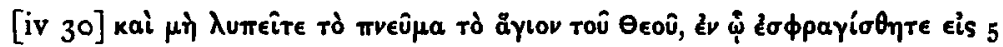

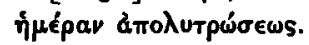

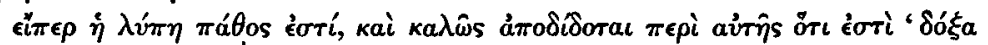

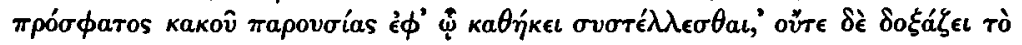

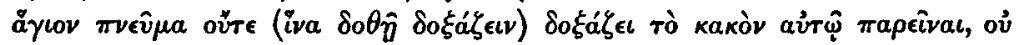

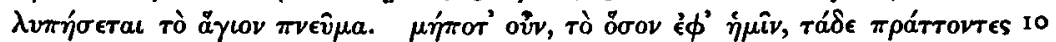

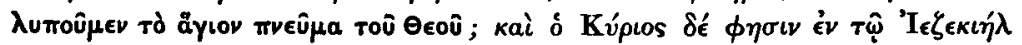

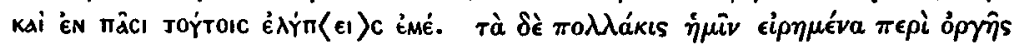

$$
\begin{array}{lrl}
\text { 12. Jo. xiii 27 } & \text { XXI 12. Ezech. Xvi } 43 \\
\text { I8-23:630 D-63IA } & \text { XXI 2-4:632A } & \text { I2-I4:632 CD }
\end{array}
$$

22. kat rav̂ra MS : possibly kard taûra 'stealing in this sense,' Turner 24.

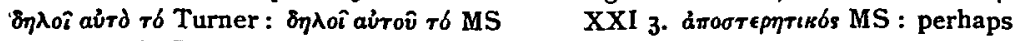

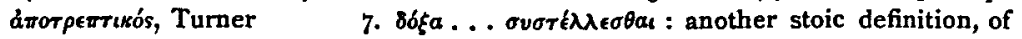
which the Greek is found in Stobaeus Eclog. ii $\$ 174$, and a Latin version in Cicero

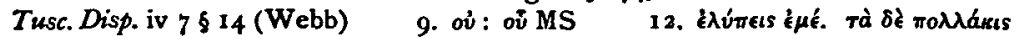

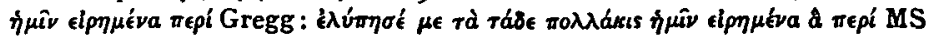




\section{$55^{6}$ THE JOURNAL OF THEOLOGICAL STUDIES}

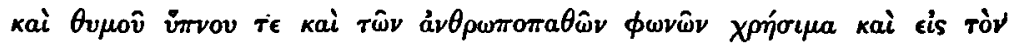

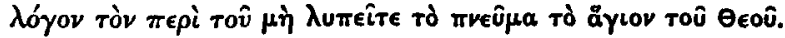

15 द̇

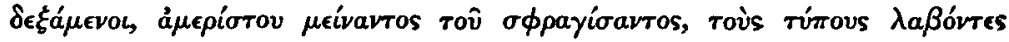

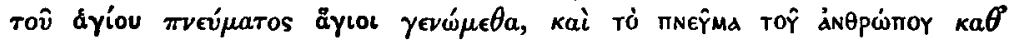

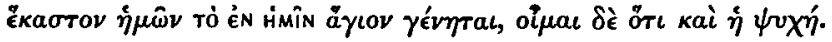

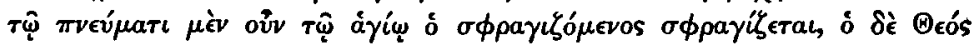

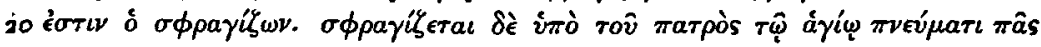

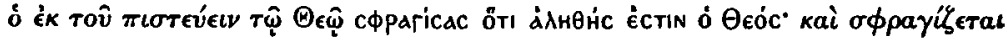

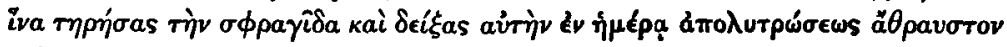

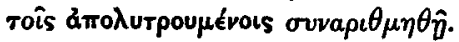

\section{$\S$ XXII.}

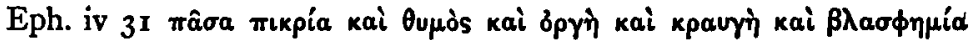

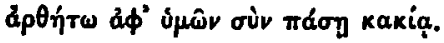

\section{['R}

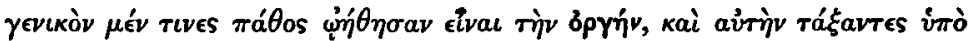

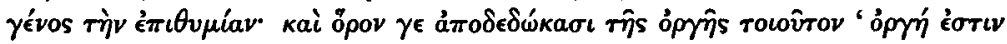

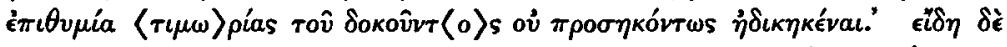

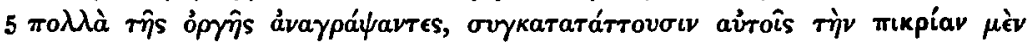

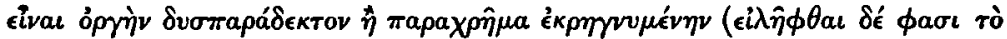

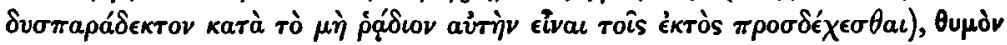

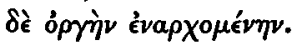

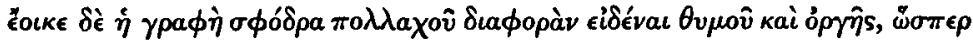

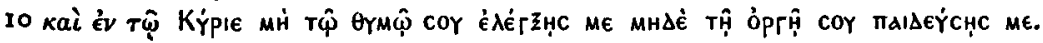

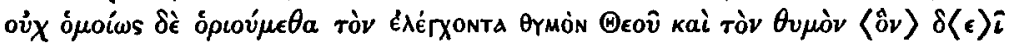

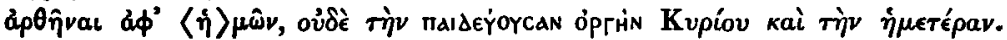

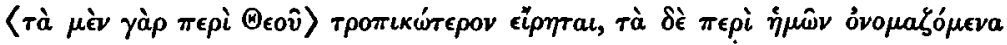

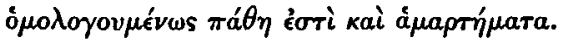

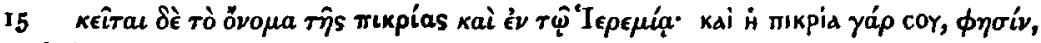

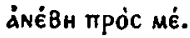

17. I Cor. ii II

$$
15^{-23}: 63^{2} \mathrm{E}-634 \mathrm{~A}
$$

XXII 10. Ps. xxxvii 2 (xxxviii I)

15. Is. xxxvii 29

$$
\text { XXII 9-14: 635 B, 636 A - I5-21: 635 A }
$$

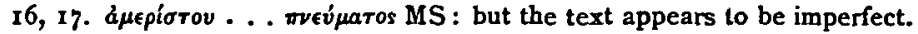

XXII 4. ripupias (cf. 1.2I and XIX 71 ) Turner : novmpias MS : the same definition of anger is found in Diogenes Laertius VII i $\$ 111$, and was plajnly taken from the

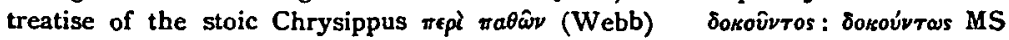

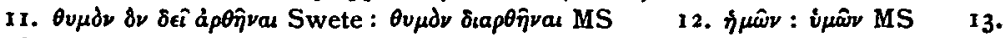

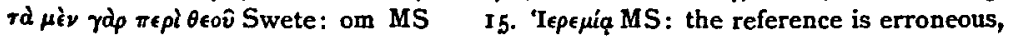
since the quotation is from Is. $\operatorname{xxxvii} 29$, but the error is presumably Origen's, since it is found also in Jerome (635 A) 


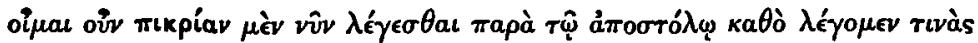

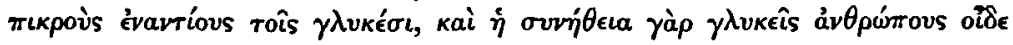

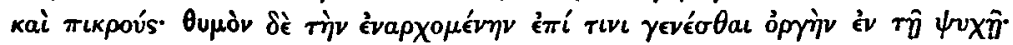

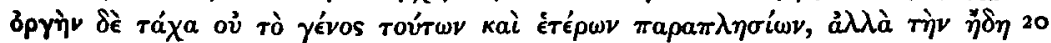

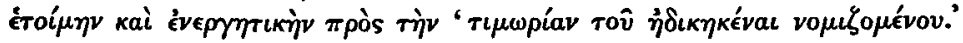

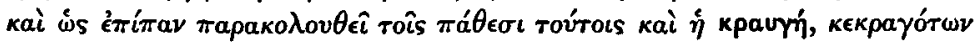

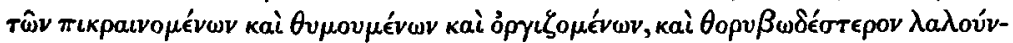

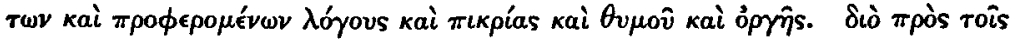

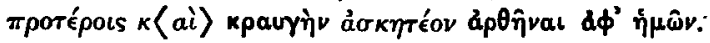

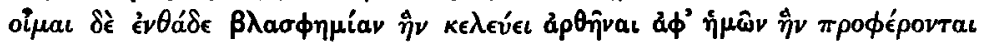

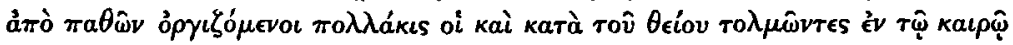

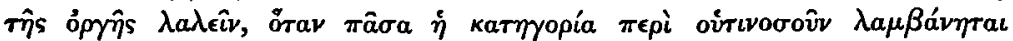

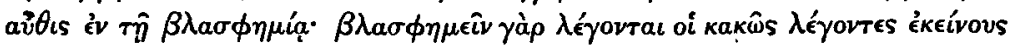

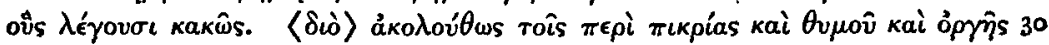

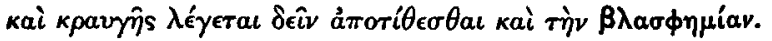

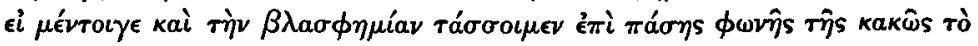

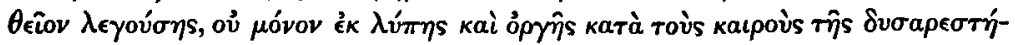

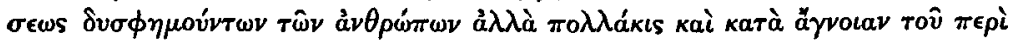

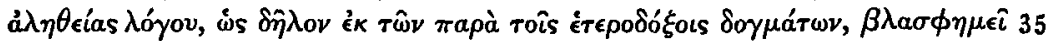

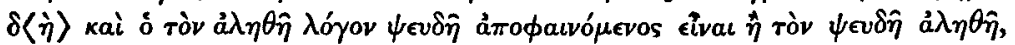

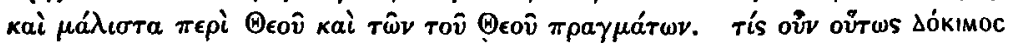

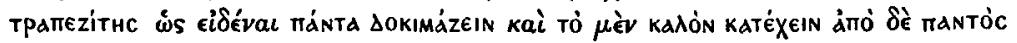

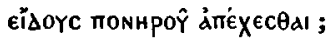

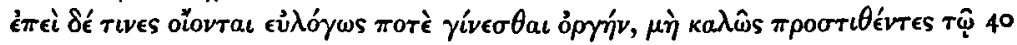

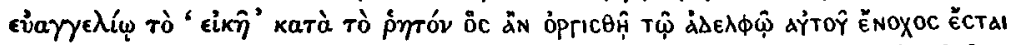

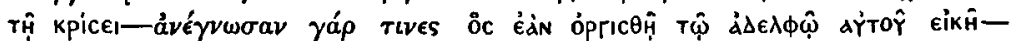

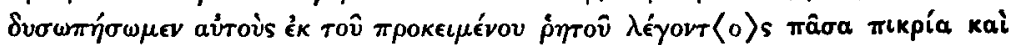

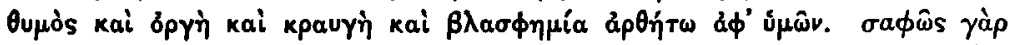

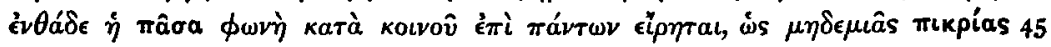

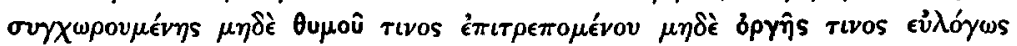

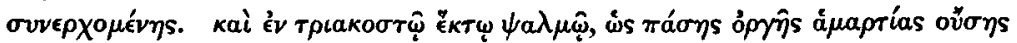

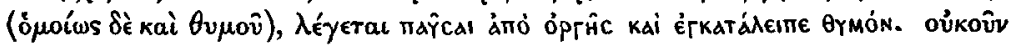

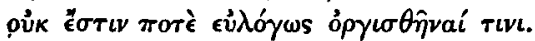

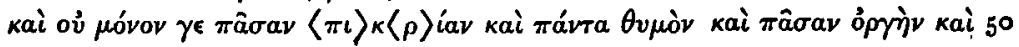

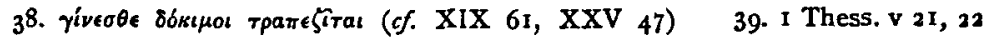
41. Matt. v $22 \quad 48$. Ps. Xxxvi (xxxvii) 8

$$
\text { 22-25:637 B } 34-39: 637 \mathrm{~B}-\mathrm{D} \quad 40-49: 636 \mathrm{~B}, 637 \AA \quad 50-52: 637 \mathrm{DE}
$$

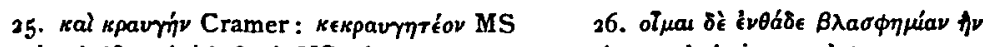

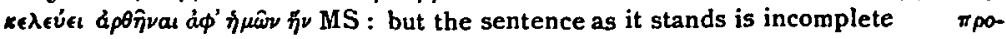

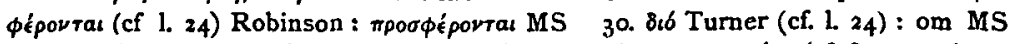

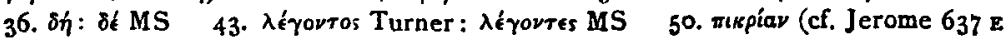
'amaritudinem ') Gregg, Robinson : kakíav MS 


\section{$55^{8}$ THE JOURNAL OF THEOLOGICAL STUDIES}

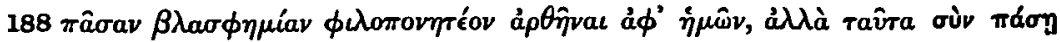

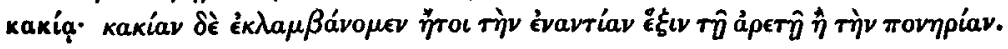

\section{$\S$ XXIII.}

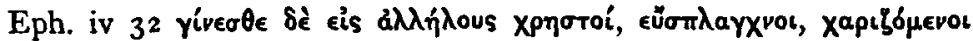

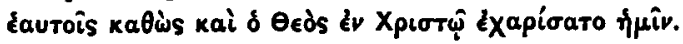

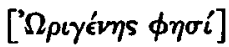

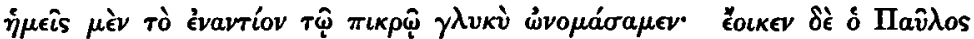

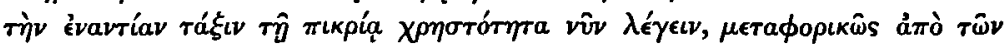

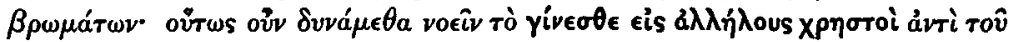

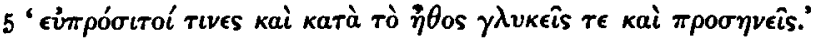

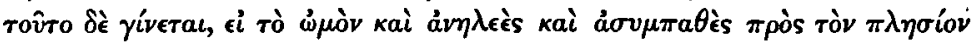

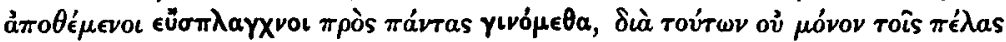

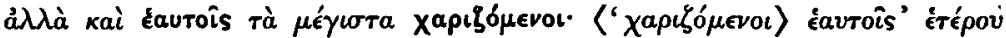

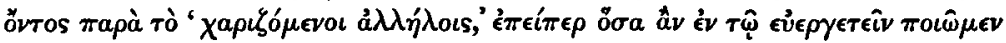

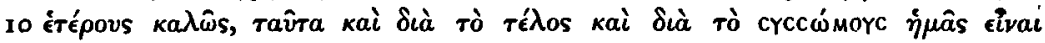

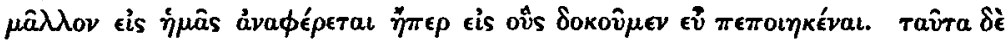

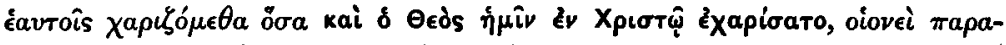

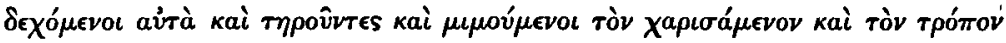

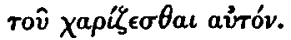

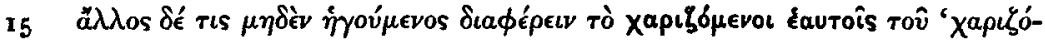

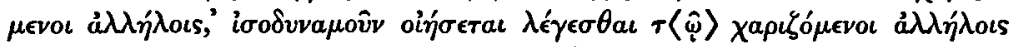

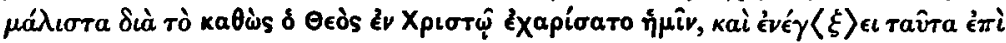
Tì å̀

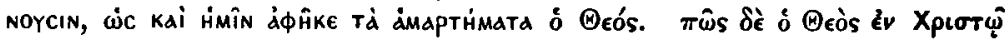

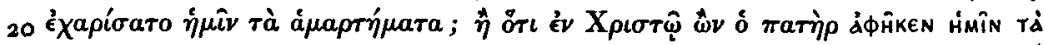

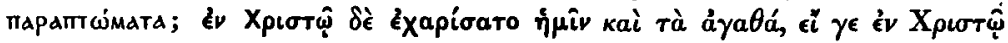

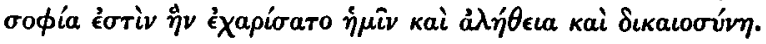

\section{$\S$ XXIV.}

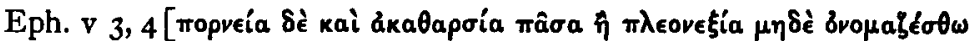

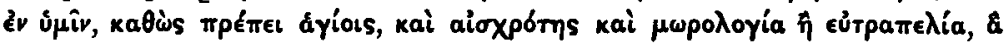

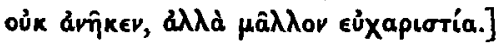

\section{XXIII ro. Eph. iii 6 I8, 20. Matt. vi I 2, I4, 15}

$$
\text { XXIII 2-5:637 E } 638 \text { A 6-14:638 A-C } \quad 1_{5-22: 638 \mathrm{C}-\mathrm{E}}
$$

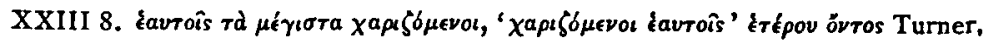

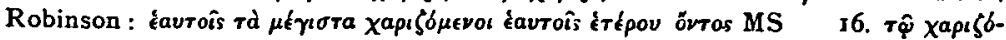

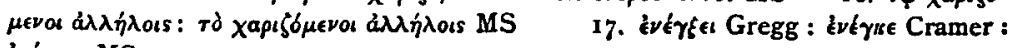

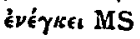




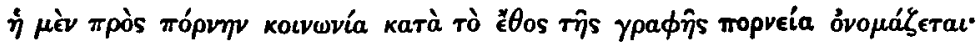

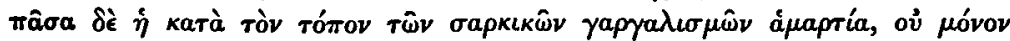

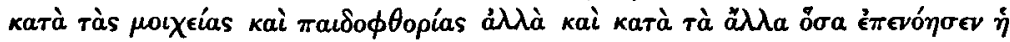

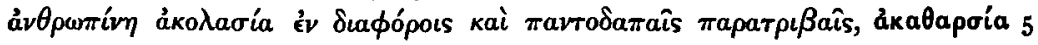

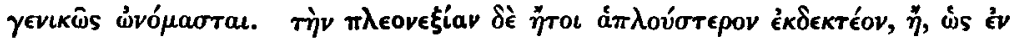

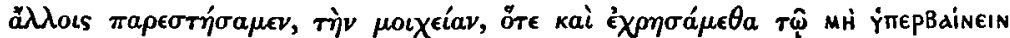

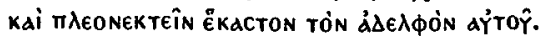

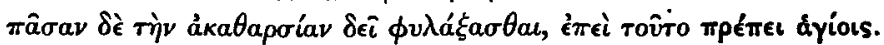

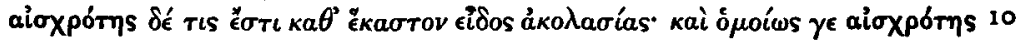

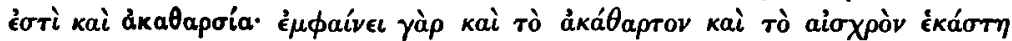

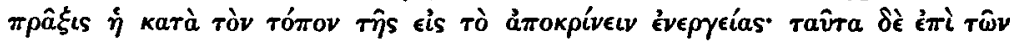

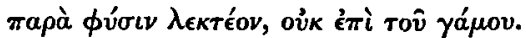

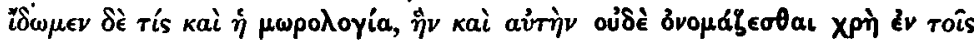

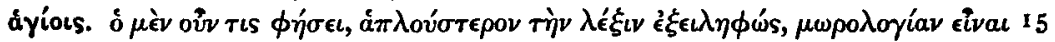

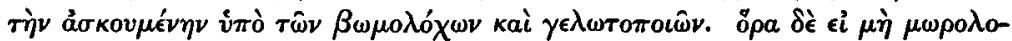

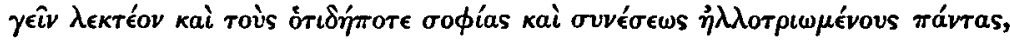

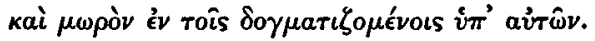

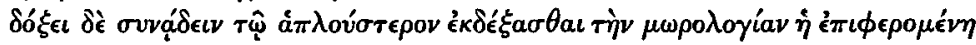

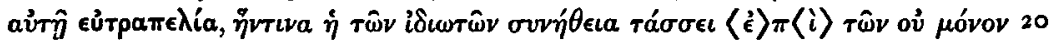

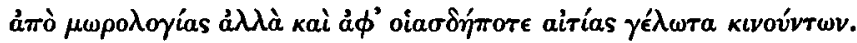

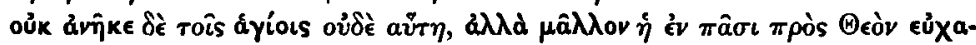

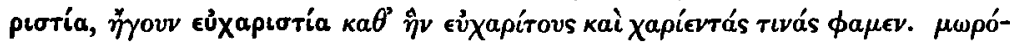

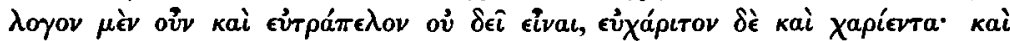

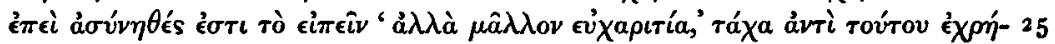

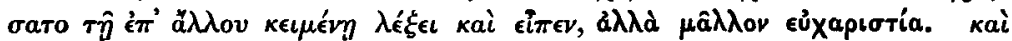

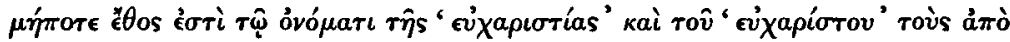

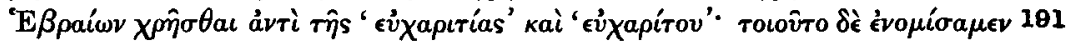

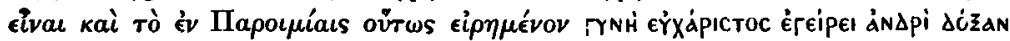

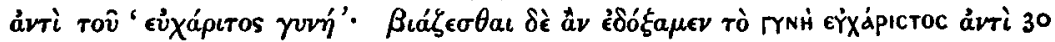

XXIV 7. I Thess. iv 4,6 29. Prov. xi 16

XXIV 6-8:640 B $\quad 15-18: 640 \mathrm{D} \quad 19-22: 640 \mathrm{E} 64 \mathrm{IA} \quad 22-33: 64^{\mathrm{I}} \mathrm{D-}$
642 $^{2} \mathrm{~A}$

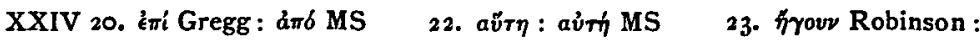

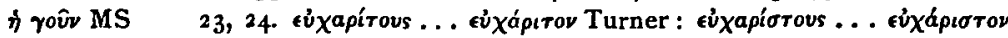
MS : comparing Jerome 64I B-D (where read '

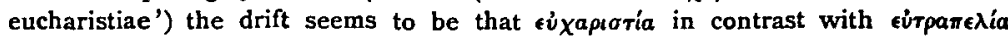
must be rather 'graciousness' than 'gratefulness'; that the form eỉxaptria, the abstract noun from cúxáptros, is not in use, and St. Paul therefore employs the noun of the neighbouring củxapioros-unless indeed (Origen adds) we go as far as to say that in Hebraistic use not only the unavoidable noun eivapiatía but the avoidable

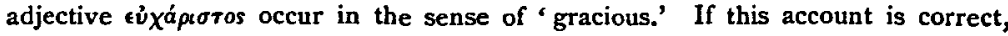

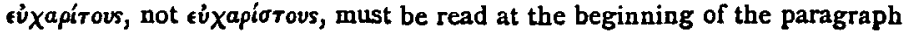




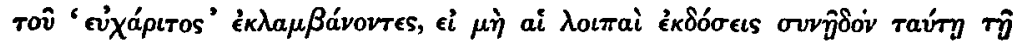

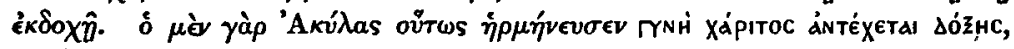

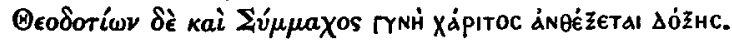

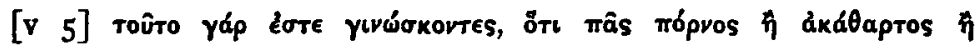

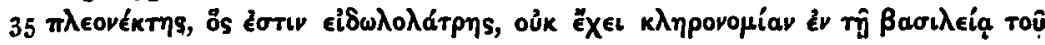
Xpıбтоù kaì Өєoù.

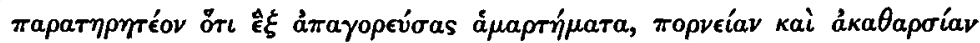

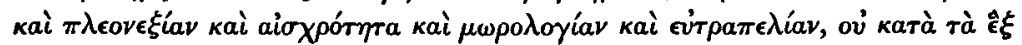

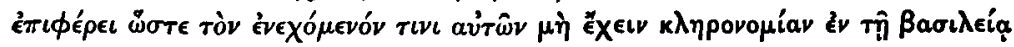

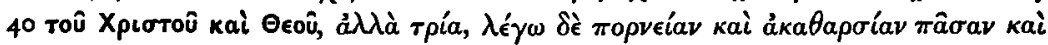

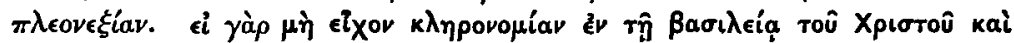

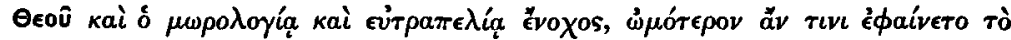

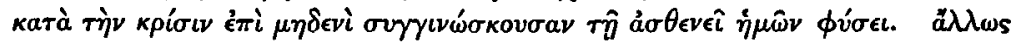

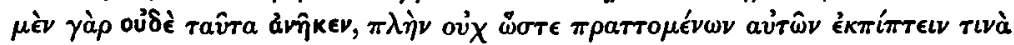

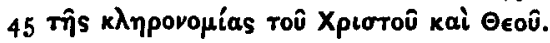

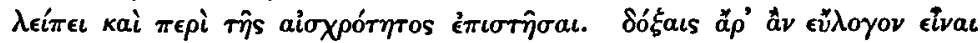

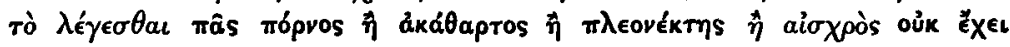

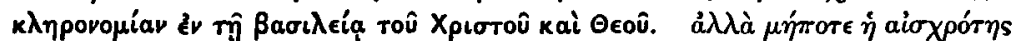

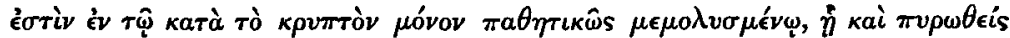

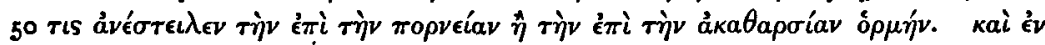

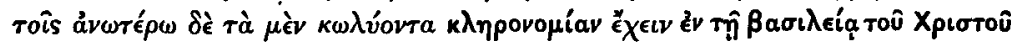

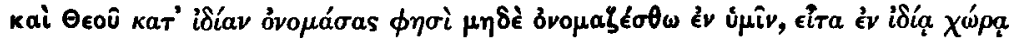

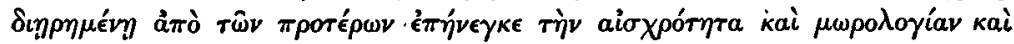

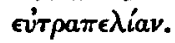

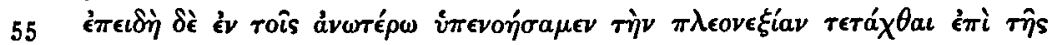

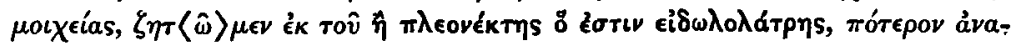

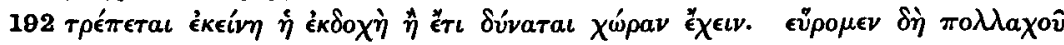

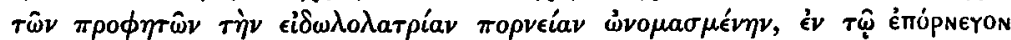

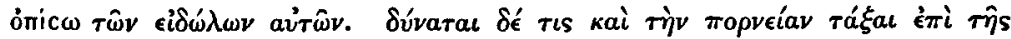

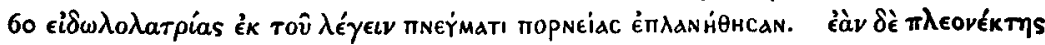

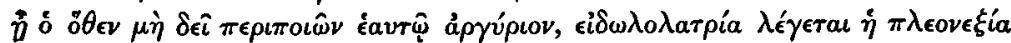

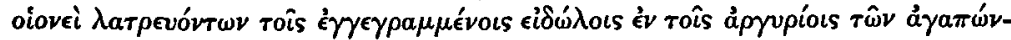

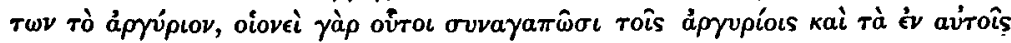

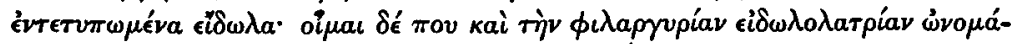

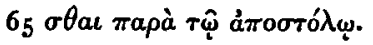

58. e.g. I Paral. v 25, Ezech. $x \times 30$ (ff. Jer. ix $1_{4}$, Sap. xiv 12) 6o. Os. iv 12

$$
37-45: 642 \text { в С } \quad 46-54: 642 \mathrm{D}-643 \mathrm{~A} \quad 55-65: 643 \mathrm{~A}-\mathrm{C}
$$

32, 33. The renderings of Aquila and Theodotion are not mentioned in Field's

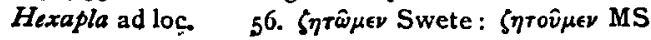




\section{$\S \mathrm{XXV}$.}

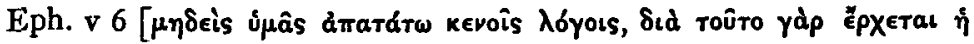

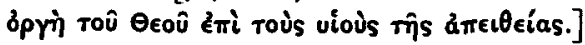

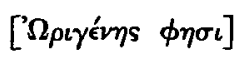

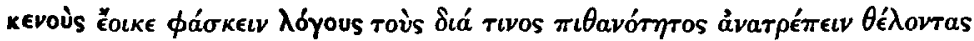

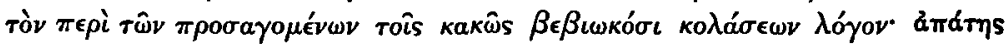

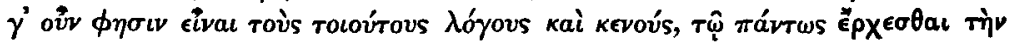

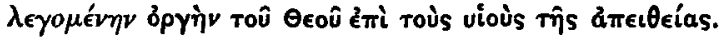

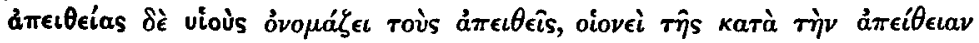

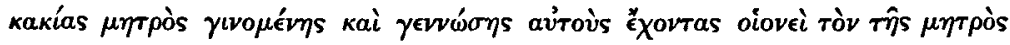

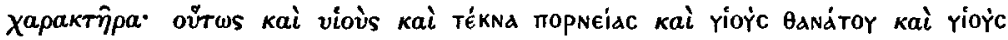

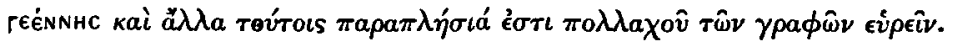

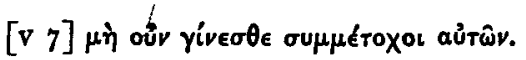

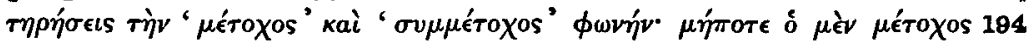

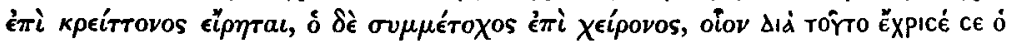

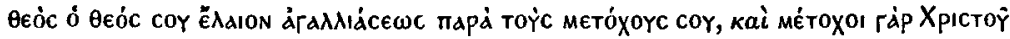

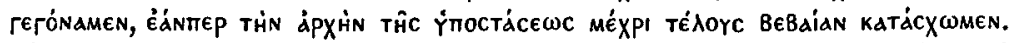

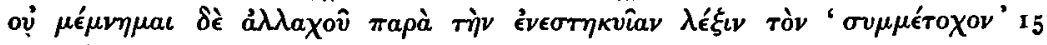

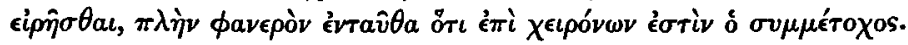

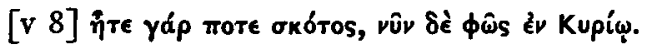

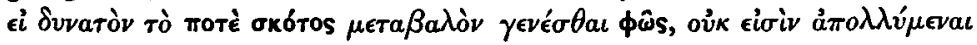
$\phi \dot{v} \sigma \epsilon i s$.

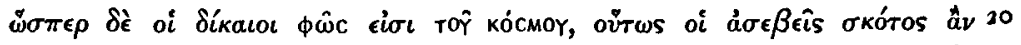

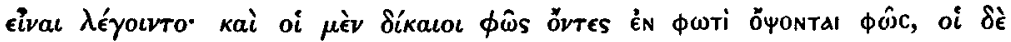

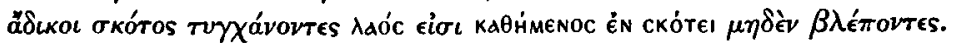

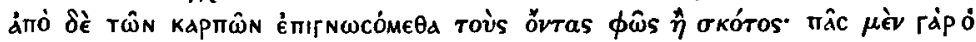

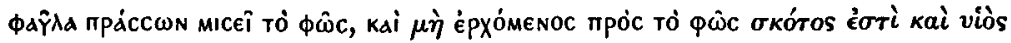

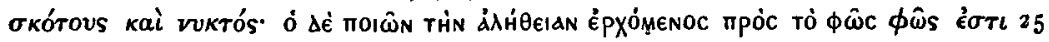

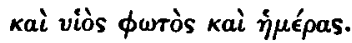

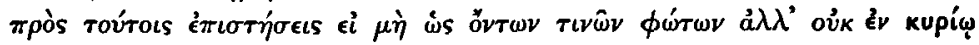

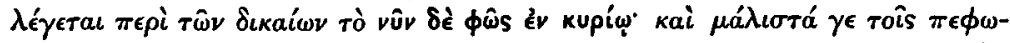

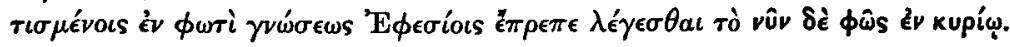

XXV 12. Ps. xliv 8 (xlv 7$) \quad$ I $_{3}$ Heb. iii $1_{4}$ 20. Matt. v I4 21. Ps. Xxxv 10 (xxxvi g) 22. Is. ix 2 23. Matt. vii 16, $20 \quad$ 23, 25. Jo. iii 20, 2 I

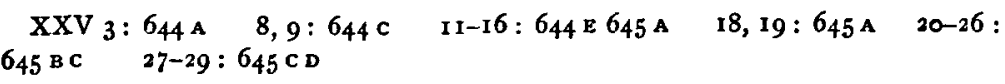

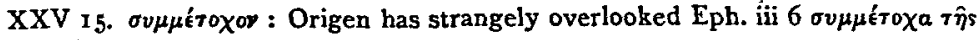

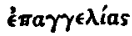

VOL. III.

00 


\section{THE JOURNAL OF THEOLOGICAL STUDIES}

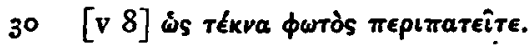

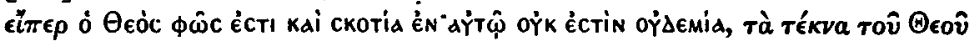
Tékva éori фwrós.

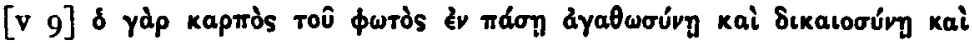

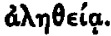

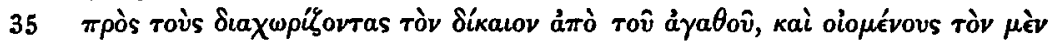

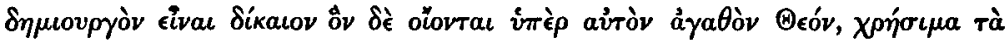

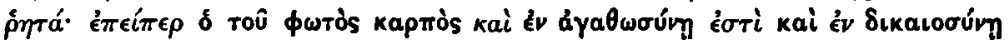

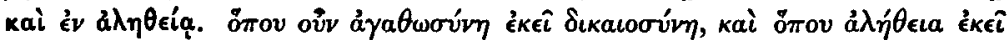

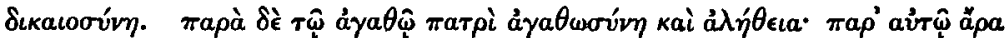

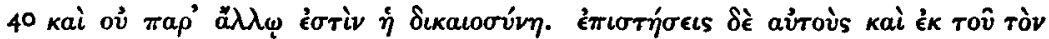

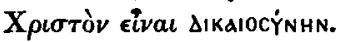

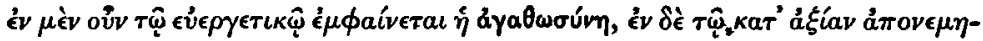

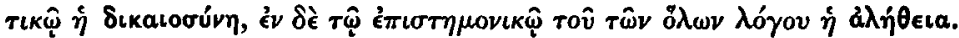

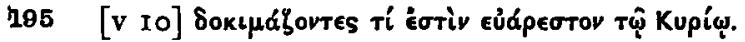

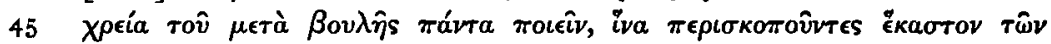

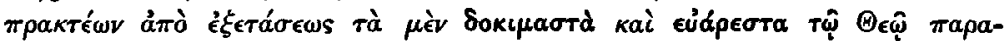

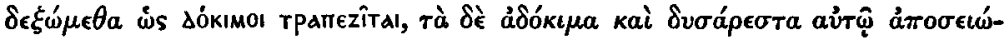
$\mu \epsilon \theta$.

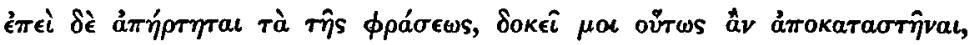

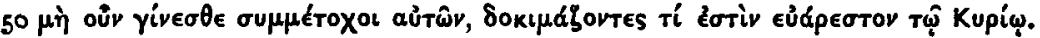

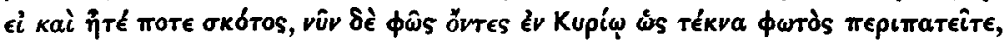

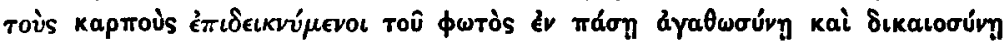

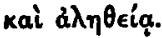

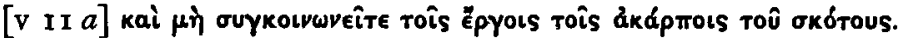

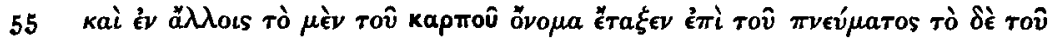

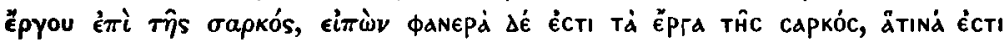

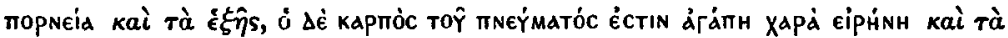

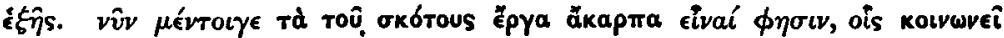

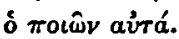

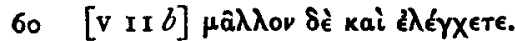

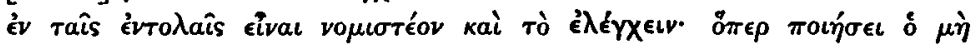

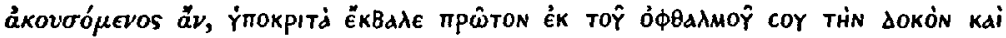

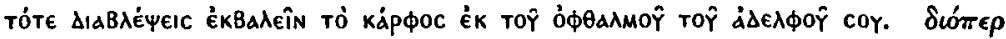

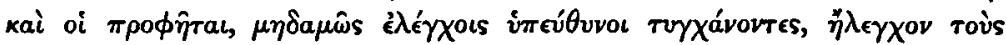
$6_{5}$ åmaprávovtas.

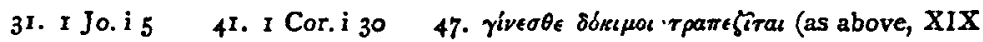
61, XXII 38) 56, 57. Gal. v 19,22 62. Matt. vii 5

$$
3 \mathrm{I}, 32: 645 \mathrm{~F} \quad 35-43: 645 \mathrm{x}-6{ }_{4} 6 \mathrm{~B} \quad 45-70: 6{ }_{4} 6 \mathrm{c}-647 \mathrm{~B}
$$




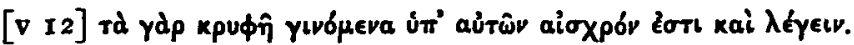

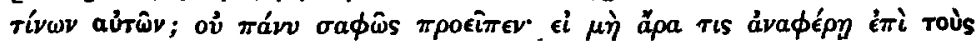

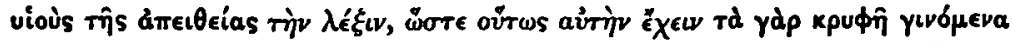

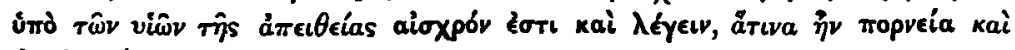
àkalapoía.

\section{§XVI.}

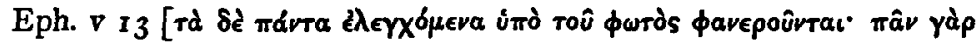

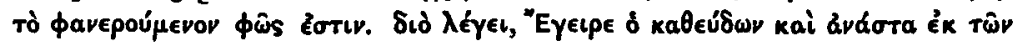

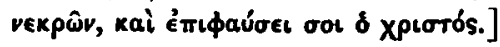

['Л

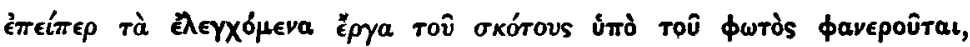

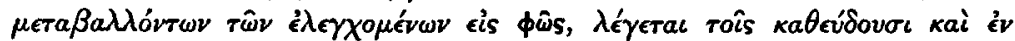

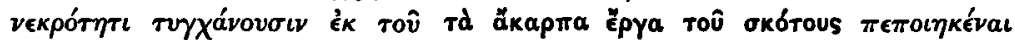

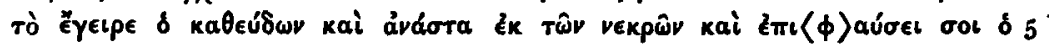
xpırós.

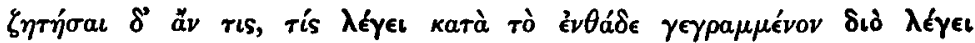

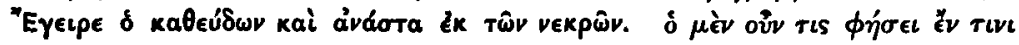

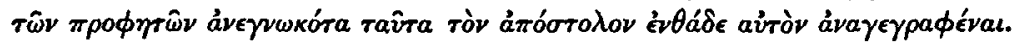

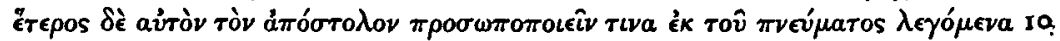

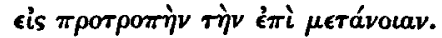

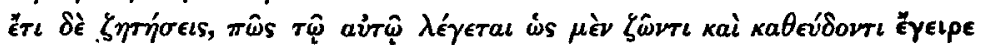

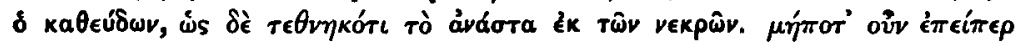

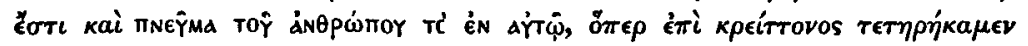

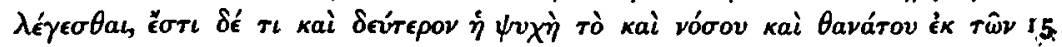

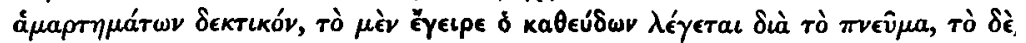

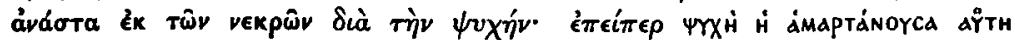

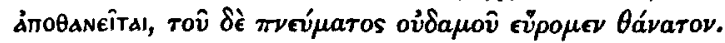

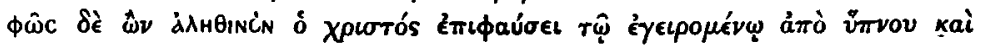

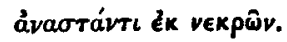

\section{$\S$ XXVII.}

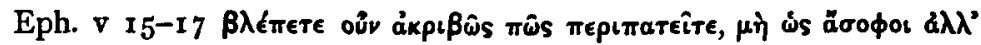

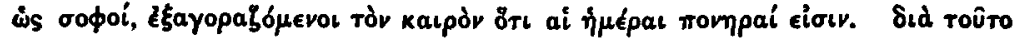

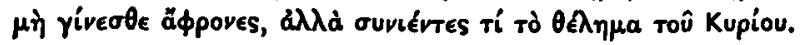

$$
\begin{array}{lll}
\text { XXVI I4 I Cor. ii II } & \text { I7. Ezech. xviii } 20 & \text { 19: Jo. i } 9 \\
\text { XXVI 2-9:647 C D } & \text { I0, II : 648 A } & \text { 12-20:648 B C }
\end{array}
$$

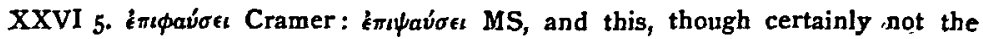
reading of Origen, was apparently the reading of the Catenist : see Swete's edition. .of Theodore ad loc. (i 180)

$$
\text { . } 02
$$




\section{THE JOURNAL OF THEOLOGICAL STUDIES}

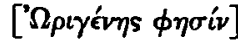

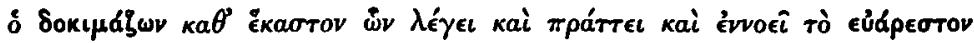

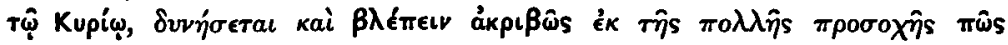

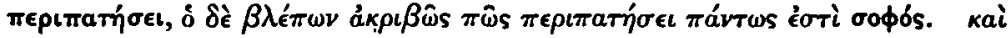

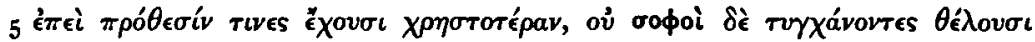

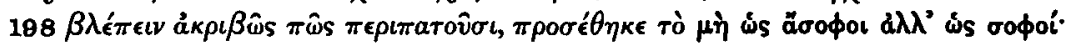

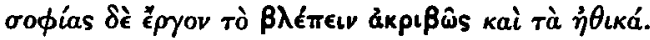

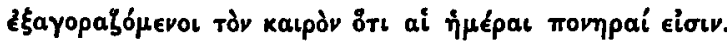

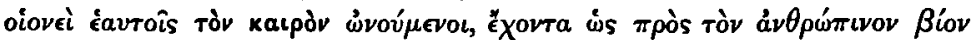

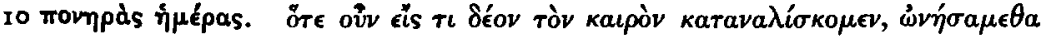

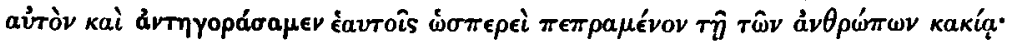

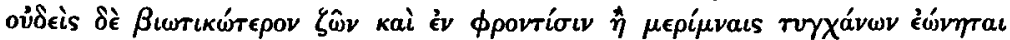

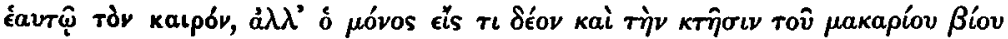
ảva入í $\kappa \omega \nu$ aủróv.

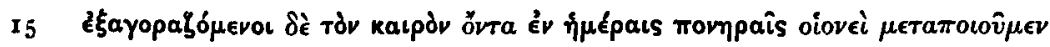

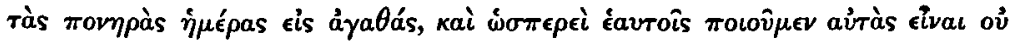

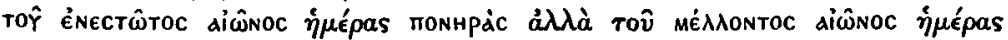
àjatás. so Kupíou.

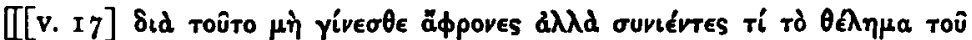

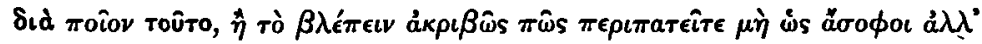

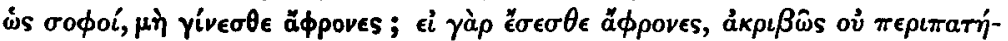

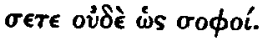

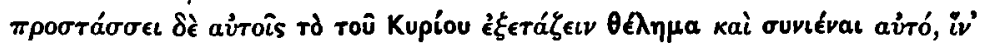

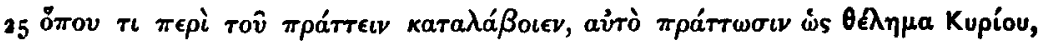

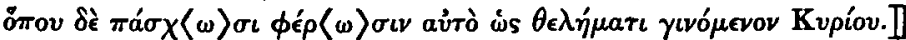

\section{$\S$ XXVIII.}

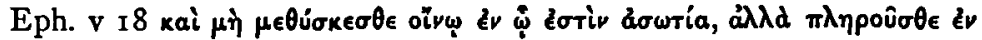

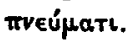

\section{$\left[' \Omega \rho \iota \gamma^{\prime} \dot{\eta} \eta \mathbf{s} \phi \eta \sigma i\right]$}

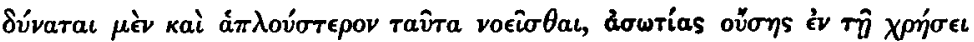

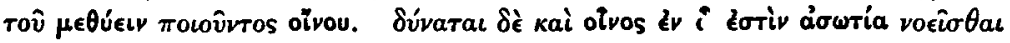

XXVII I7. Gal. i 4 ; Heb. vi 5

$$
\text { XXVII 2-7:649 в } \quad 9-18: 649 \mathrm{z} \quad \text { XXVIII } 3-6: 651 \mathrm{~B}
$$

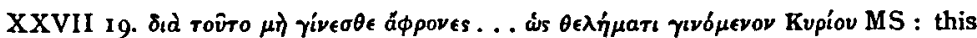
verse and the comment on it are written in the MS continuously with the comments of Origen on $v v_{1} 15,16$; but the style here seems to savour of Severian rather than of Origen, and the passage is therefore printed within double brackets (Gregg)

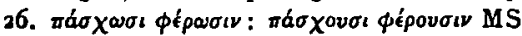




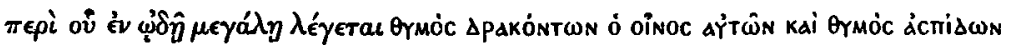

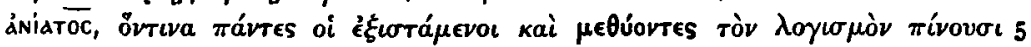

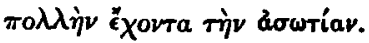

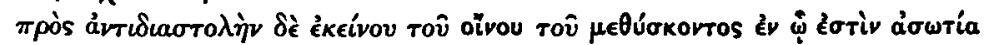

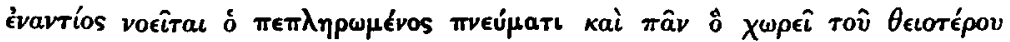

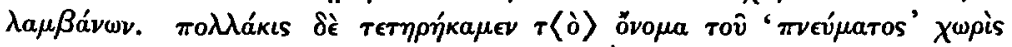

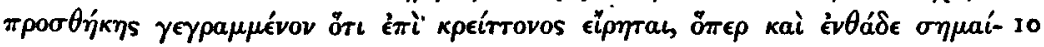
vetal.

\section{$\S$ XXIX.}

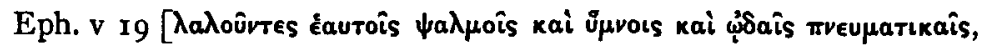

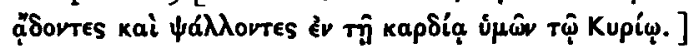

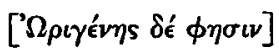

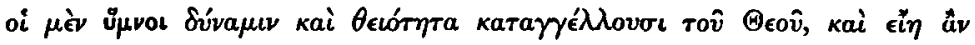

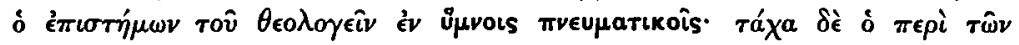

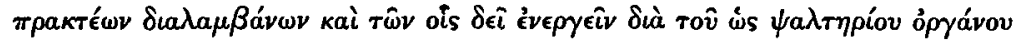

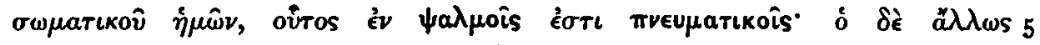

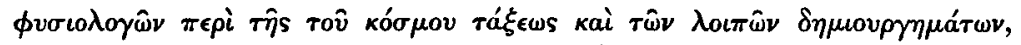

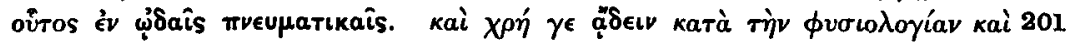

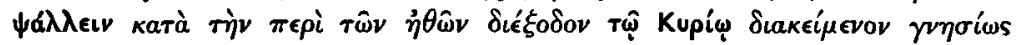

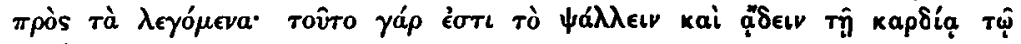
Kupị́.

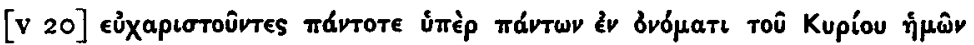

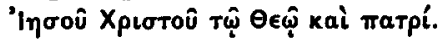

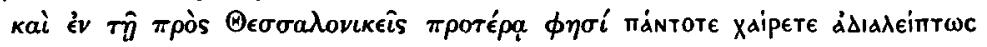

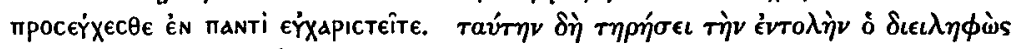

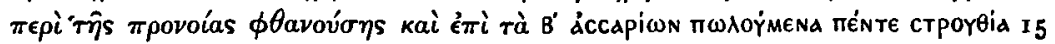

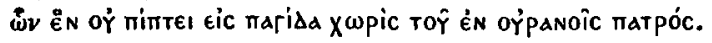

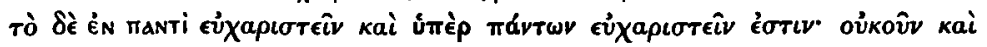

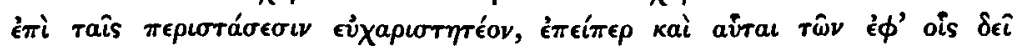

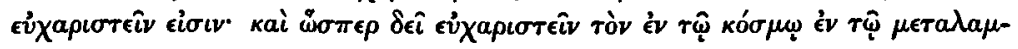

XXVIII 4. Deut. xxxii $33 \quad X_{1 X}$, 17. I Thess. $\operatorname{II}_{16-18}$ 15, 16. Luc. xii 6; Matt. x 29

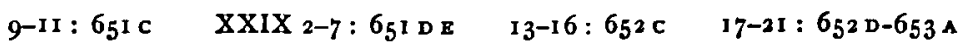

XXVIII 9. тd ö

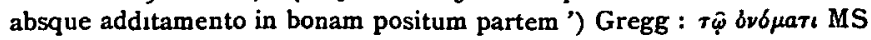

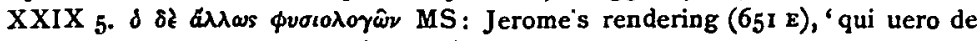
superioribus disputat,' suggests ävo for ấlhas (Turner) 


\section{THE JOURNAL OF THEOLOGICAL STUDIES}

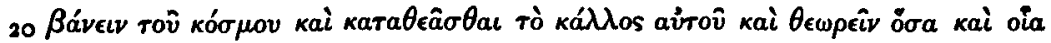

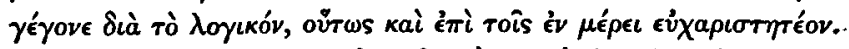

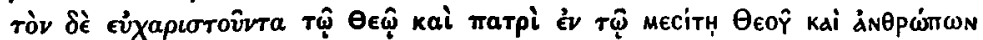

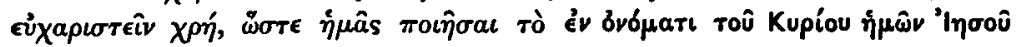

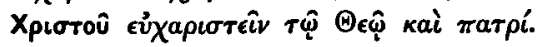

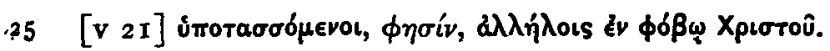

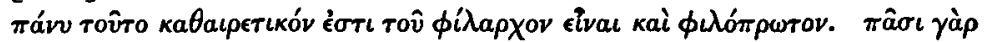

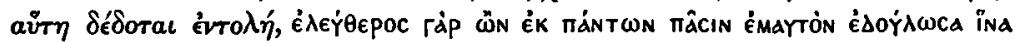

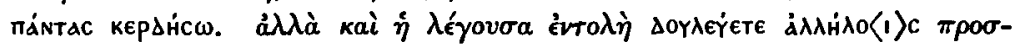

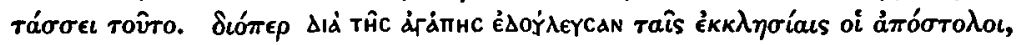

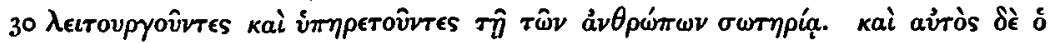

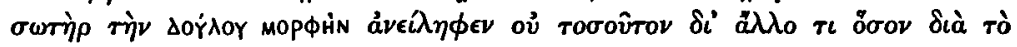

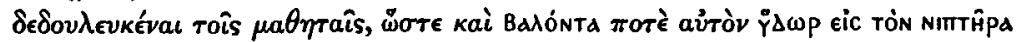

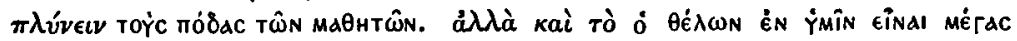

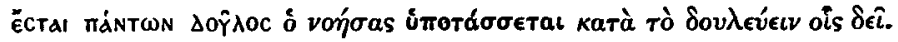

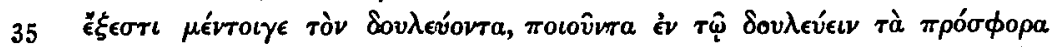

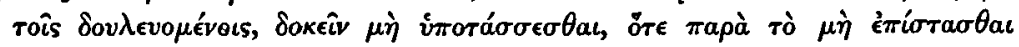

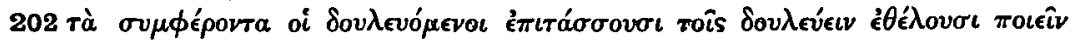

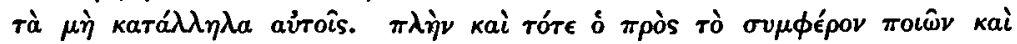

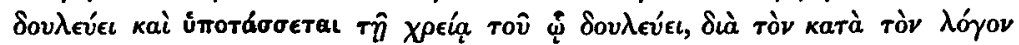

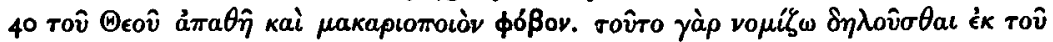
év $\phi \dot{\beta} \beta \omega$ X

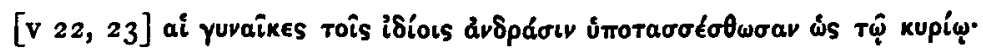

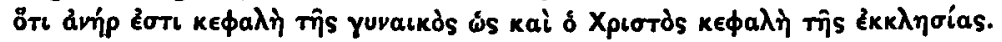

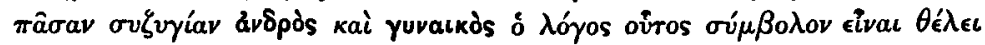

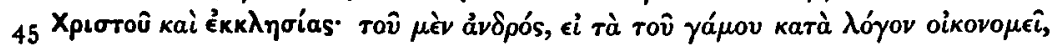

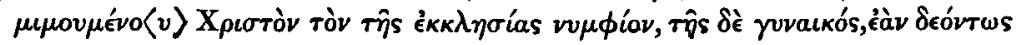

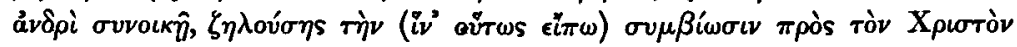

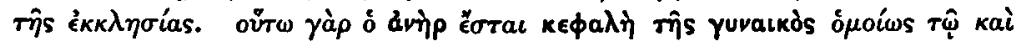

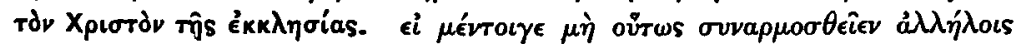

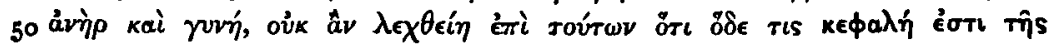

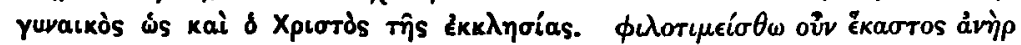

22. I Tim. ii 5 27. I Cor. ix 19 28. Gal. v I3 31 . Phil. ii $7 \quad$ 32. Jo. xiii 5 33. Matt. 2026,27

$23,24: 653 \mathrm{D} \quad 26-34: 653 \mathrm{DE}$

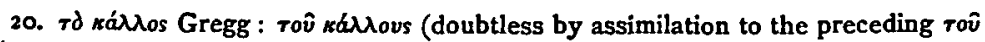

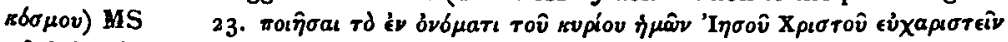

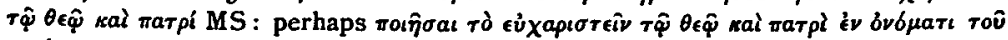

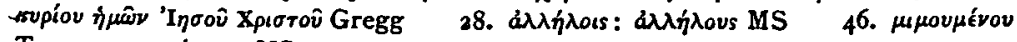

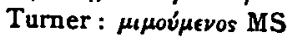




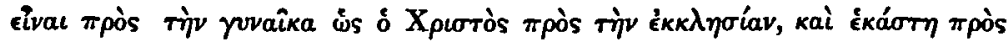

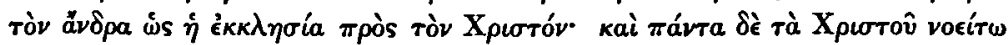

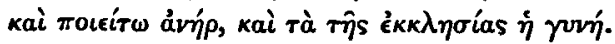

\section{$\S \mathrm{XXX}$ :}

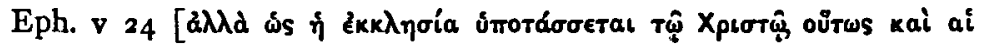

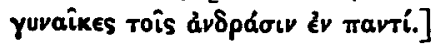

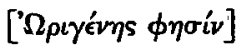

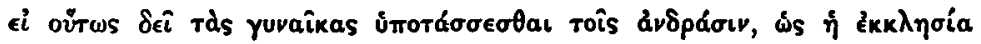

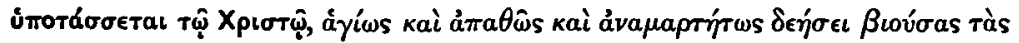

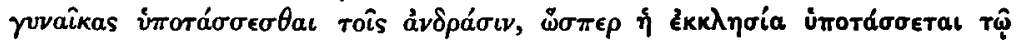

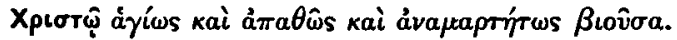

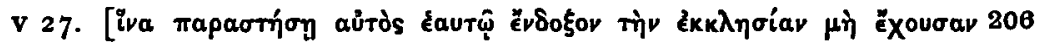

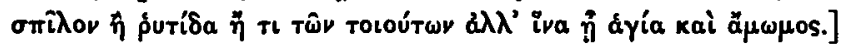

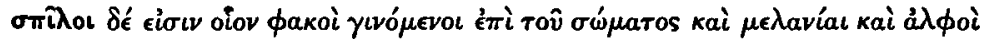

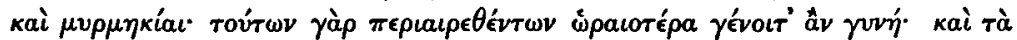

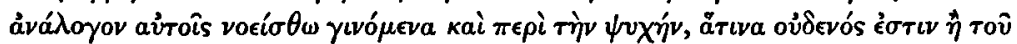

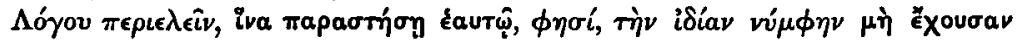

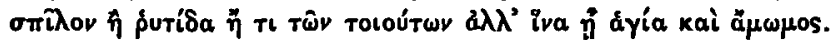

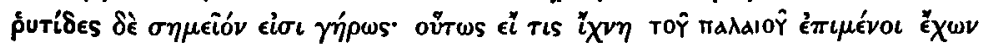

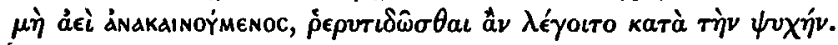

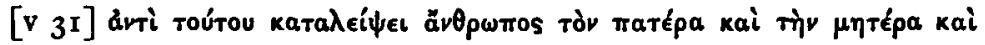

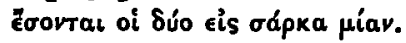

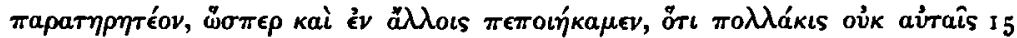

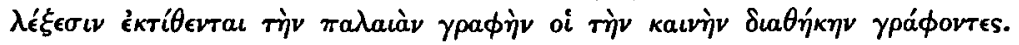

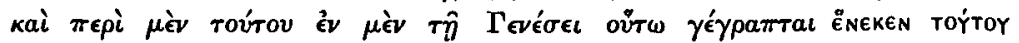

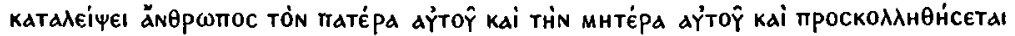

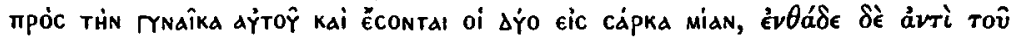

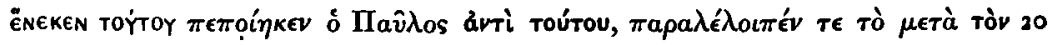

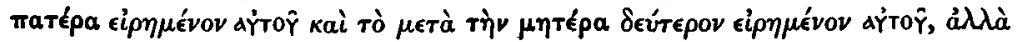

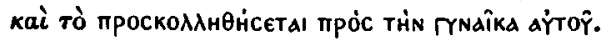

\section{$\S$ XXXI.}

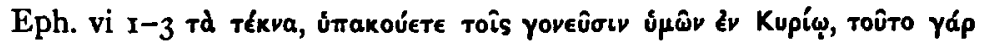

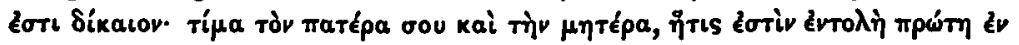

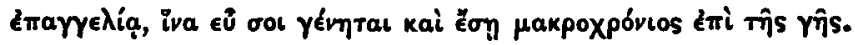

XXX I1, I2. Col, iii 9, 10 (ff. Eph. iv 22-24) I7. Gen. ii 24.

$\mathrm{XXX}_{2}-5: 6_{55} \mathrm{D} \quad 6_{-12}: 657 \mathrm{CD} \quad \mathrm{I}_{5-22}: 659 \mathrm{C}-\mathrm{E}$

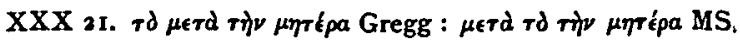




\section{THE JOURNAL OF THEOLOGICAL STUDIES}

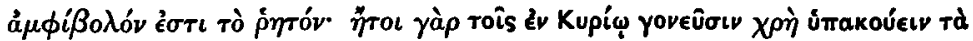

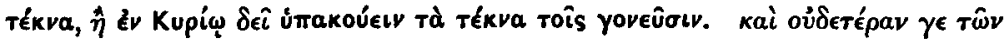

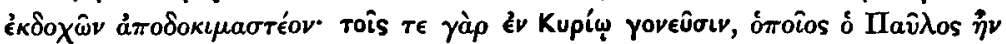

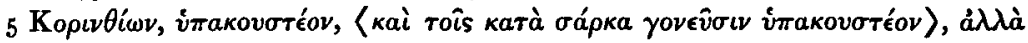

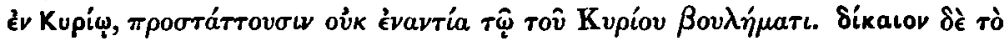

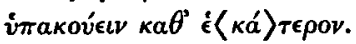

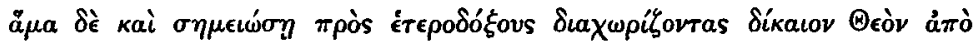

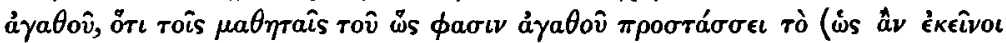

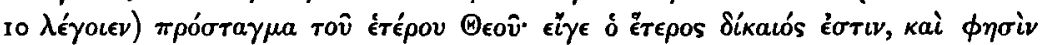

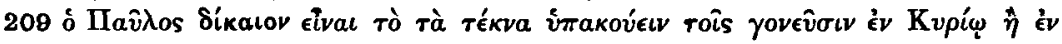

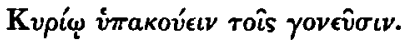

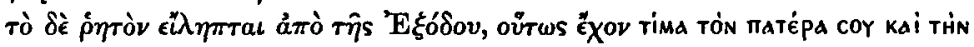

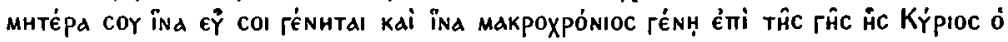

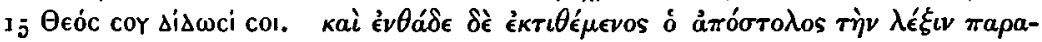

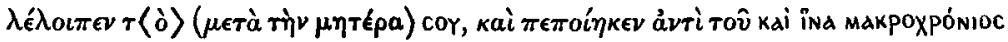

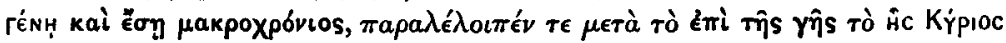
ó $\theta$ eóc cor síswci col.

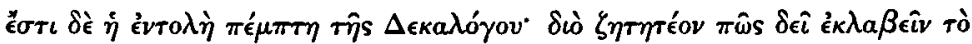

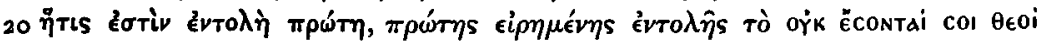

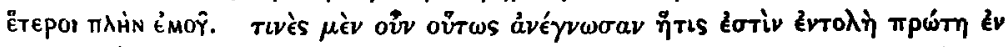

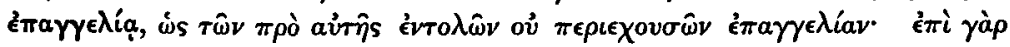

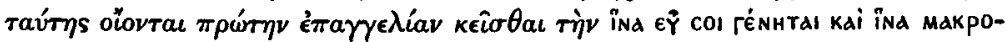

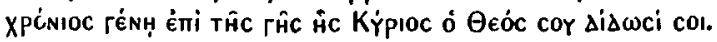

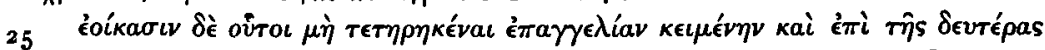

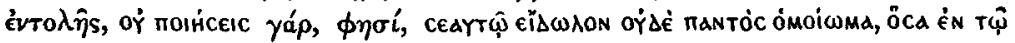
ởPan

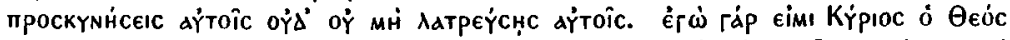

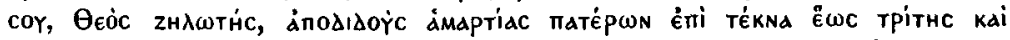

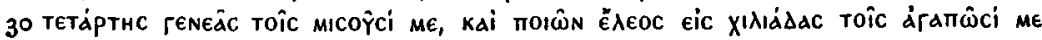

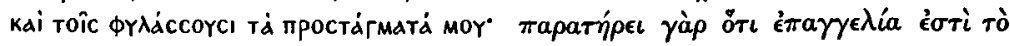

XXXI 4. I Cor. iv 15

26. Exod. $x \times 4^{-6}$
13. Exod. $x x$ 12, Deut. v 16

20. Exod, $x \times 3$

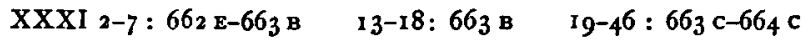

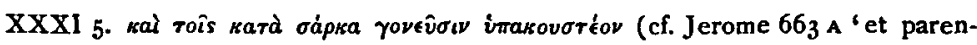
tibus nostris de quibus secundum nati sumus obtemperamus') Gregg : om (doubtless

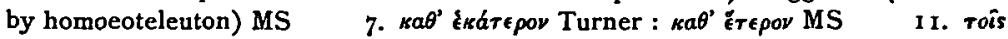

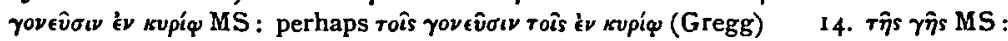

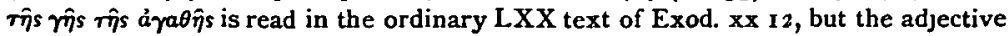
is absent throughout both in our MS (lines $17,24,38,42,45$ ) and in Jerome, so that the reference here is presumably not to Exod. xx 12, but to the Decalogue in

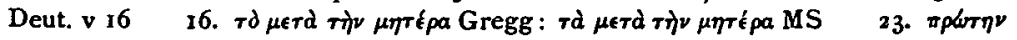
MS : possibly $\pi$ purtis (Robinson) 


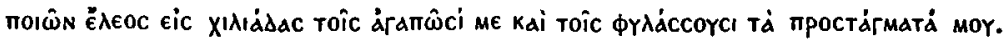

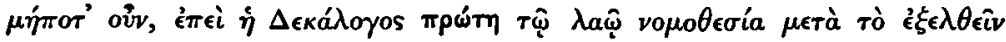

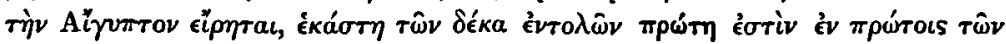

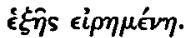

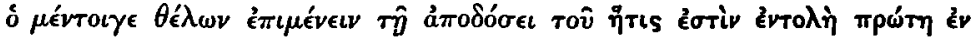

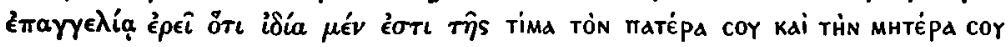

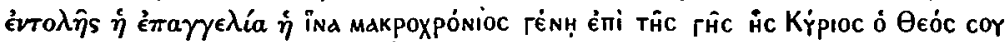

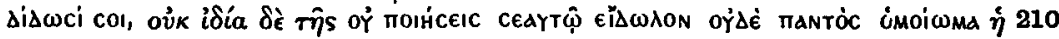

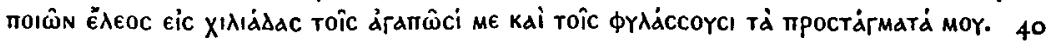

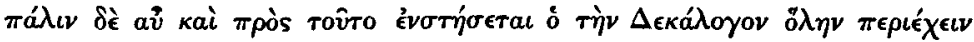

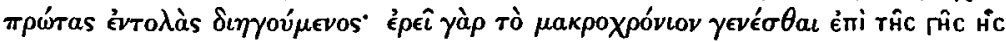

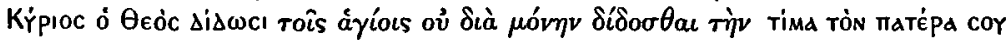

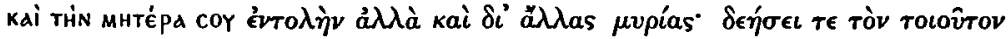

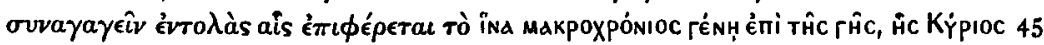
ò $\theta e o ́ c$ coY diswci cor.

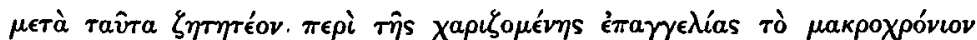

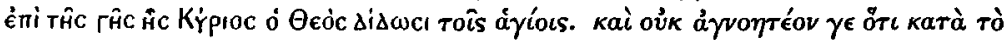

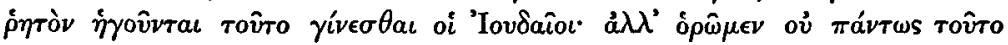

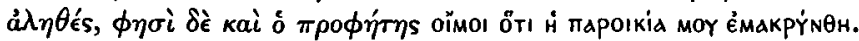

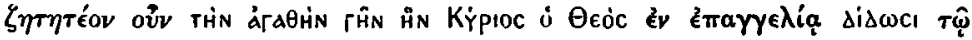

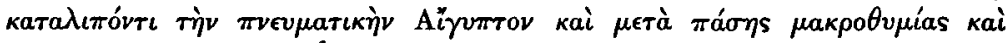

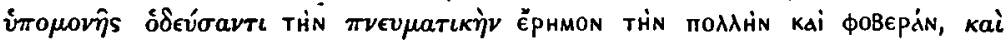

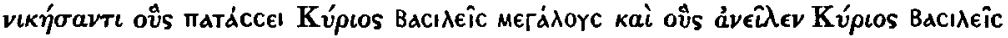
кратаIOÝc.

$\S$ XXXII.

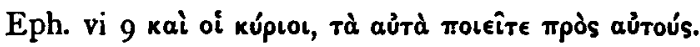

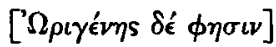

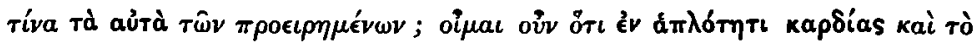

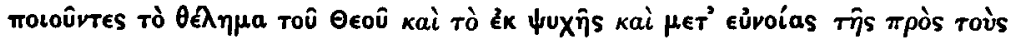
oikétas.

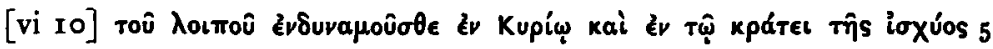
aủToû.

50. Ps. cxix (cxx) $5 \quad$ 51. cf. Deut. i $35 \quad$ 53. Deut.i $19 \quad$ 54, 55. Ps. cxxxv (cxxxvi) it, 18

$$
\text { 47-50:664 DE } \quad 1-55: 66_{5} \mathrm{C} \quad \text { XXXII 2-4:668 E }
$$

39. il: 7 MS 44-46. The Catena appears to have omitted a sentence, for not only do these two lines suggest that an answer will be made to them, but Jerome $\left(66_{4} \mathrm{CD}\right)$ shows us what it was, 'a quo diuersus ille exigere debebit interpres, ut doceat ante hoc mandatum illa quae ab eo prolata sunt scripta esse mandata; quod si non potuerit adprobare, frustra et in aluis praeceptis hanc repro-

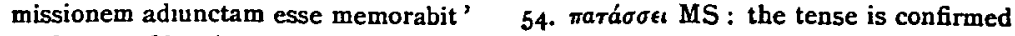
by Jerome $66_{5}$ c ' percutit' 


\section{THE JOURNAL OF THEOLOGICAL STUDIES}

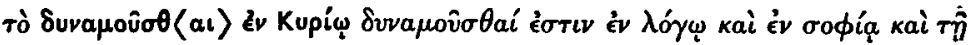

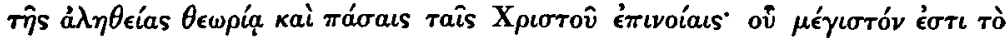

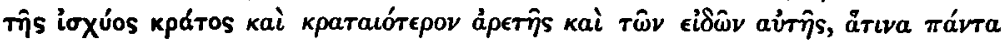

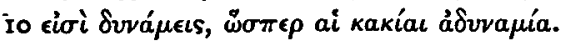

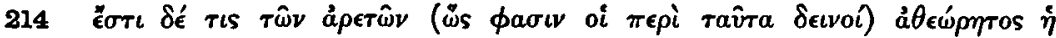

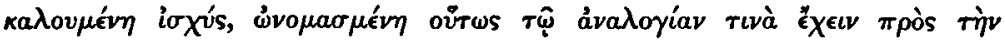

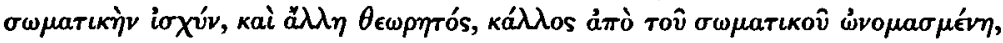

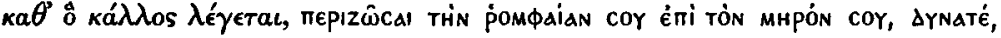

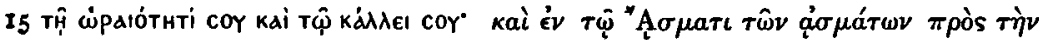

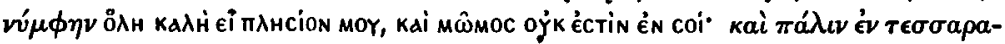

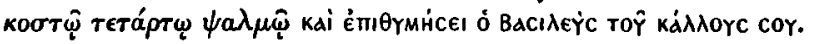

\section{$\S$ XXXIII.}

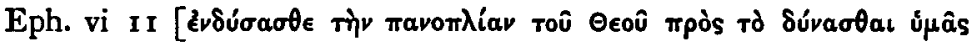

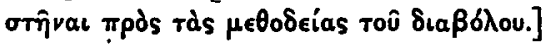

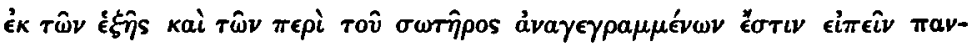

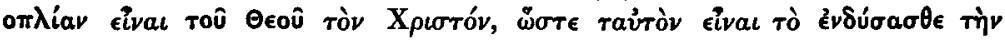

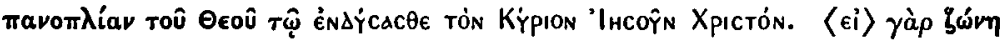

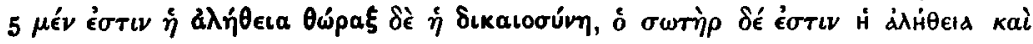

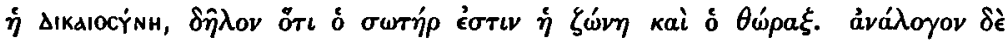

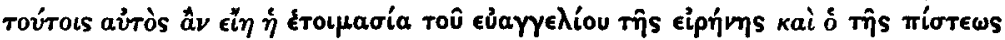

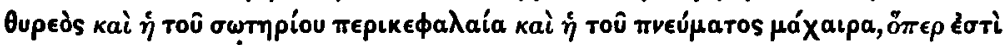

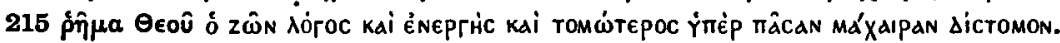

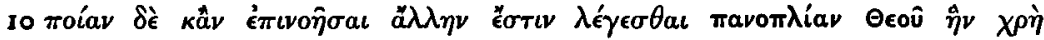

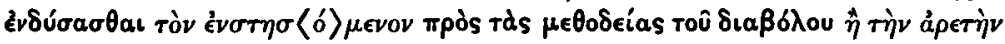

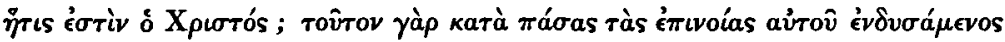

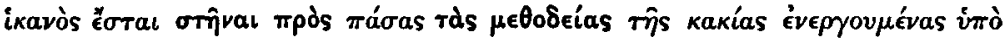

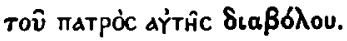

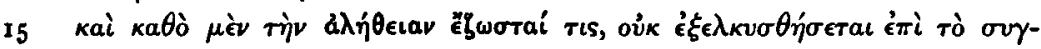

XXXII 14. Ps. xliv 4 (xlv 3) 16. Cant. iv 7 17. Ps. xliv r2 (xlv II) XXXIII 4. Rom. xiii $14 \quad$ 5. Jo. xiv $6 \quad$ 6. 1 Cor. i $30 \quad$ 9. Heb. iv 12 14. Jo. viii 44

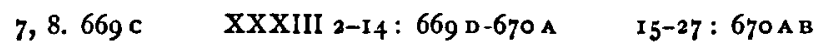

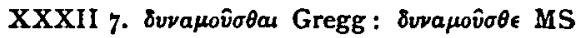

1I. Where does this definition of loxv́s come from?

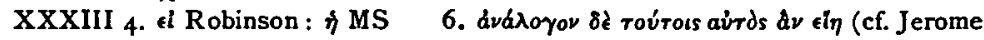

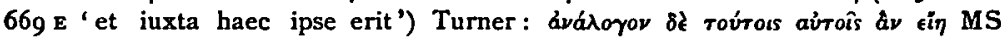

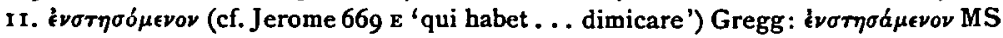

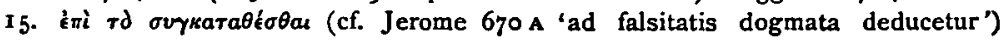

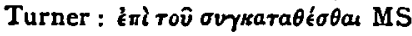




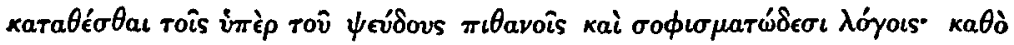

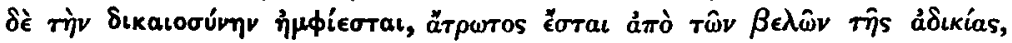

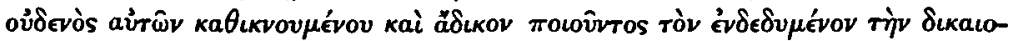

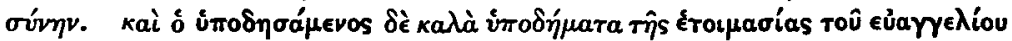

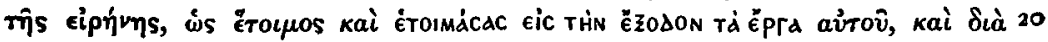

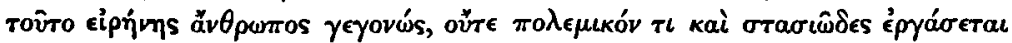

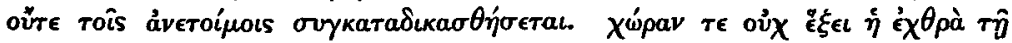

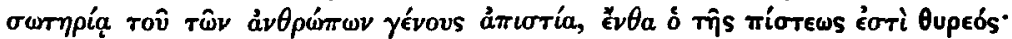

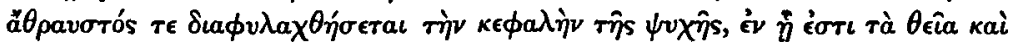

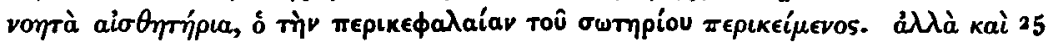

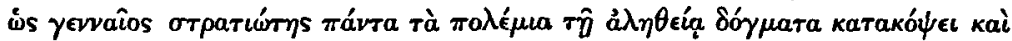

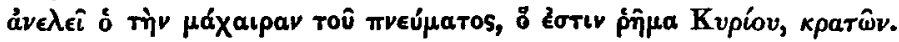

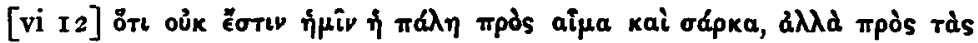

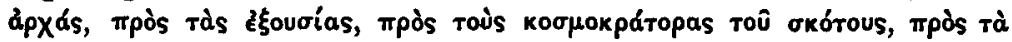

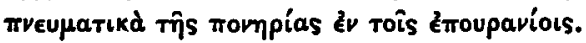

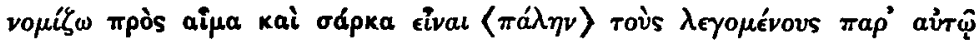

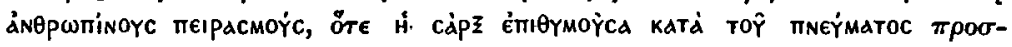

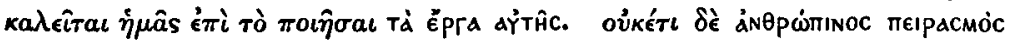

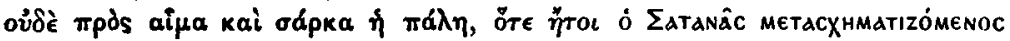

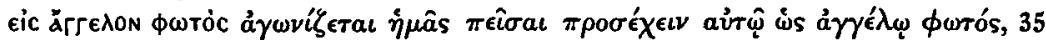

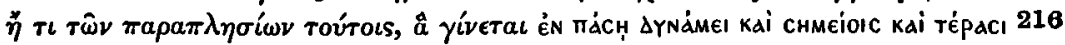

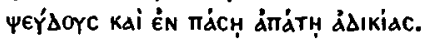

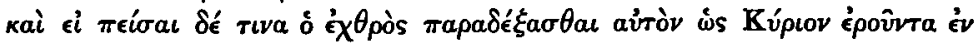

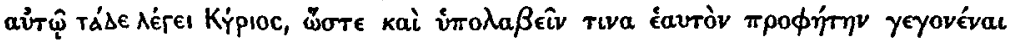

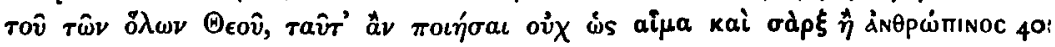

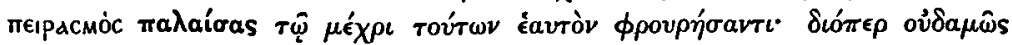

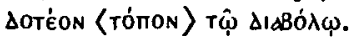

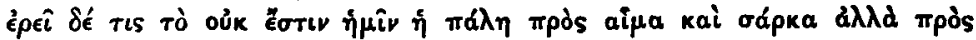

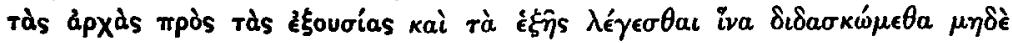

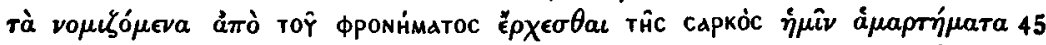

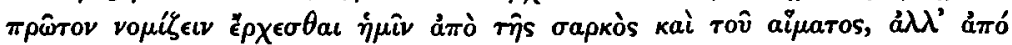

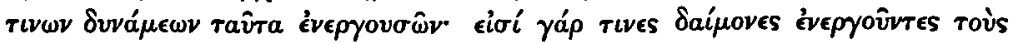

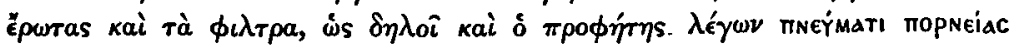

20. Prov. xxiv $42(27) \quad$ 32, 33. I Cor. x 13; Gal. v 17,19 ; 36. 2 Thess. ii 9 , 10

$3^{1-42}: 6718 \mathrm{C}$
42. Eph. iv 27

45. Rom. viii 6,7

34. 2 Cor. xi $r_{4}$

48. Os. iv 12

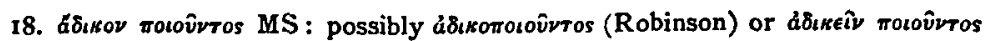
(Turner) 31. $\pi \dot{d} \lambda \eta \nu$ (cf. Jerome 671 A 'existimo quippe aduersus carnem et

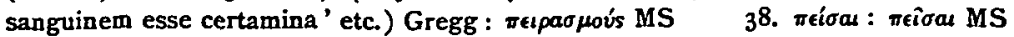

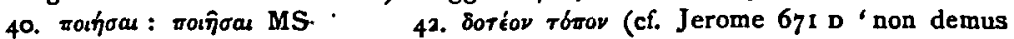
locum ') Gregg : Sortor MS 44. $r d \dot{\alpha} \xi \hat{\eta} s$ Cramer : $\tau \dot{d} s \hat{\xi} \xi \hat{\eta} s$ MS. 


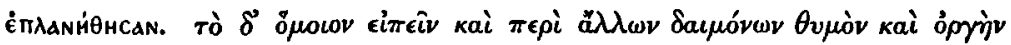

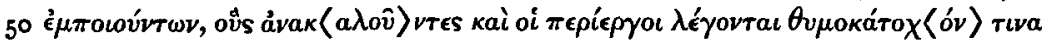

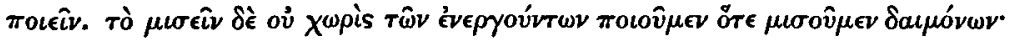

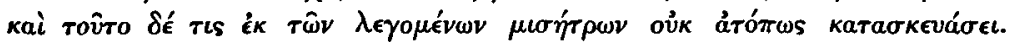

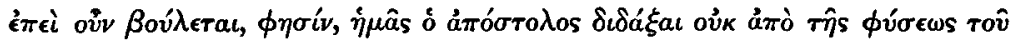

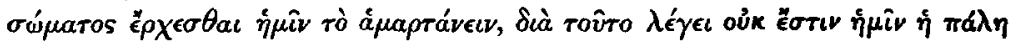

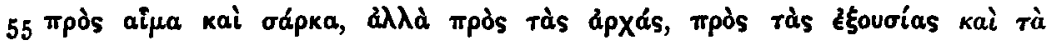
$\dot{\epsilon} \xi \hat{\eta} s$.

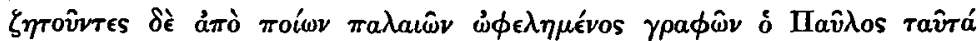

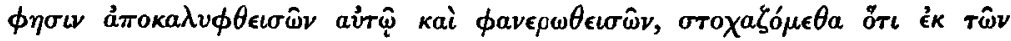

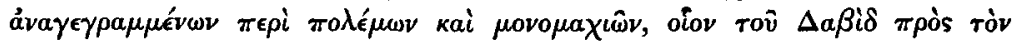

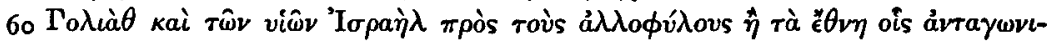

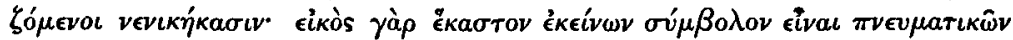

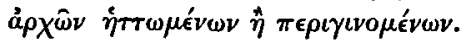

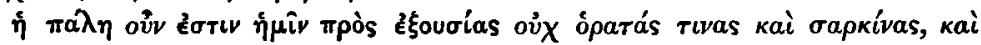

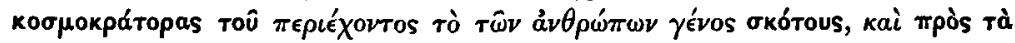

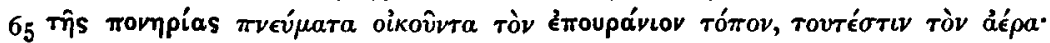

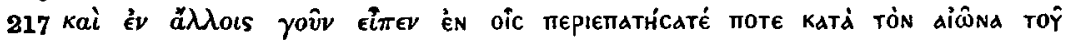

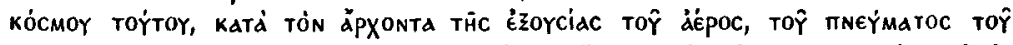

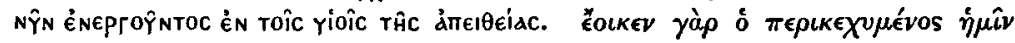

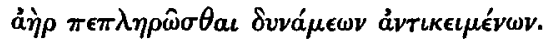

\section{$\S$ XXXIV.}

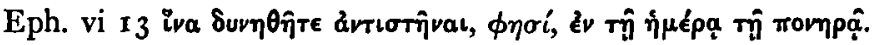

218

\section{[' $\left.\Omega \rho \iota \gamma^{\prime} v \eta \boldsymbol{s}\right]$}

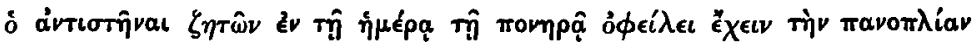

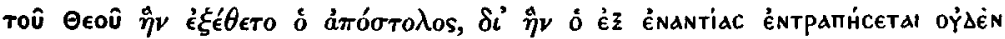

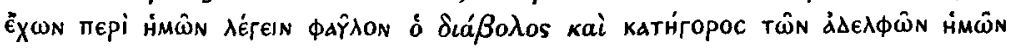

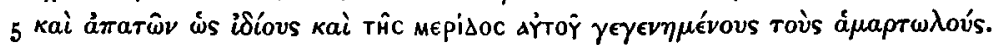

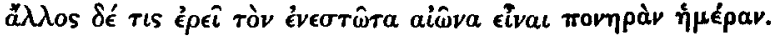

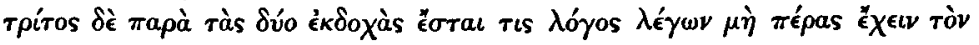

66. Eph. ii 2 24, i 16

$57-62: 672 \mathrm{E}, 673 \mathrm{~A} \quad 63-69: 673 \mathrm{c}-674 \mathrm{~A}$ $676 \mathrm{E} 677 \mathrm{~A} \quad 7-10: 677 \mathrm{E}$
XXXIV 3. Tit. ii 8

$$
63-69: 673 c-674 A
$$

5. Sap. ii

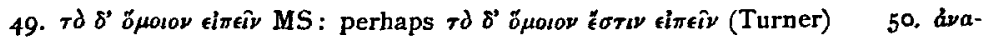

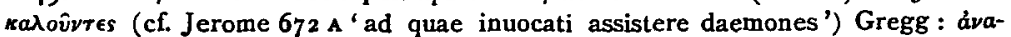

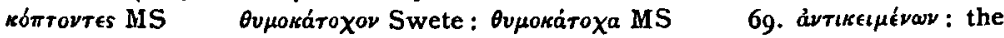
words that follow in Cramer, ö $\tau \iota$ où are really the lemma (from Eph. vi I2) for the comment from Chrysostom which follows : cf. supra XII 49 


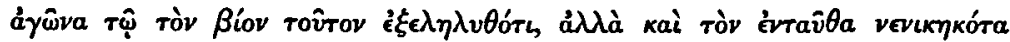

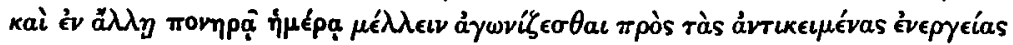

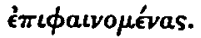

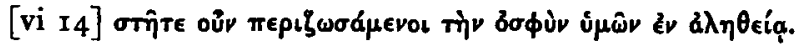

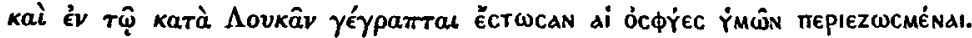

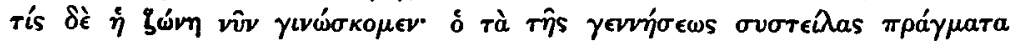

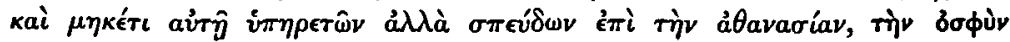
לśnvutal.

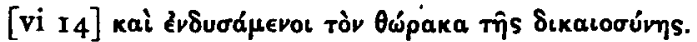

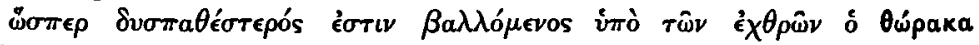

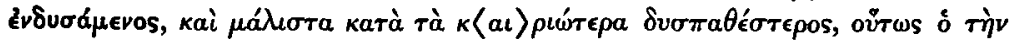

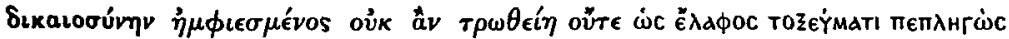

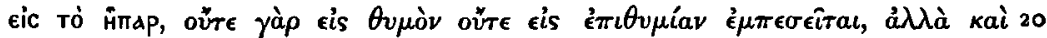

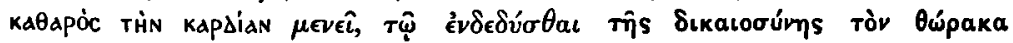

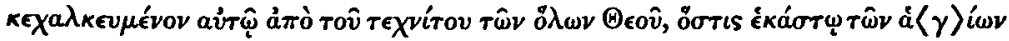

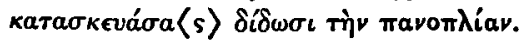

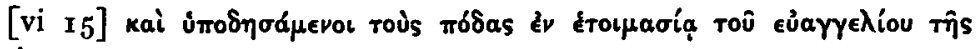
Eipńrns.

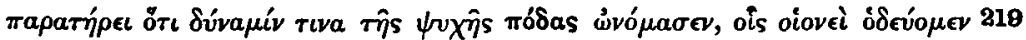

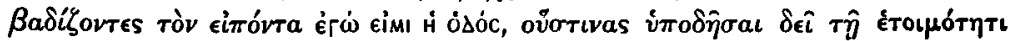

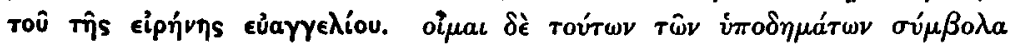

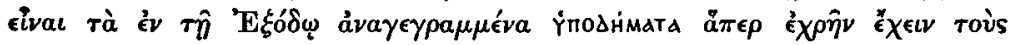

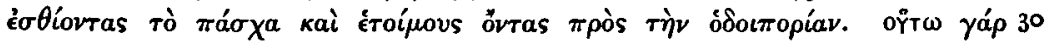

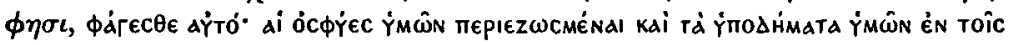

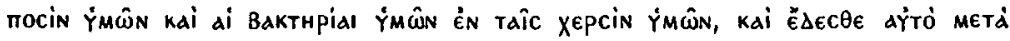

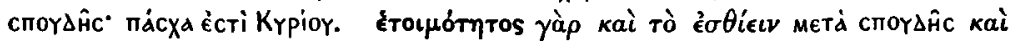

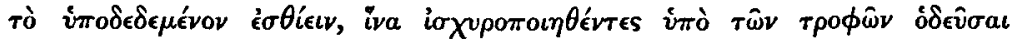
$\delta \nu \nu \eta \theta \hat{\omega} \sigma \iota \nu$.

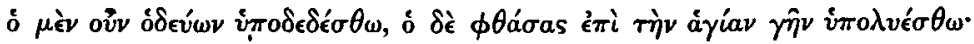

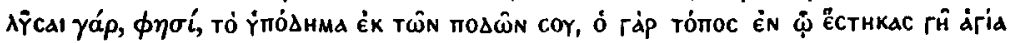
écrí.

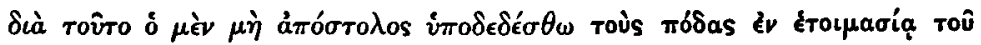

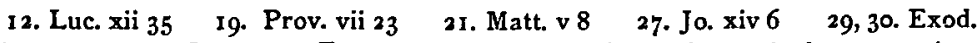
xii 11 37, 41. Jos. V I5; Exod. iii 5 ( $=$ Act vii 33 ): the former is the appropriate parallel, the latter is more strictly similar in wording

. 12-15:678CE 26-43:679B-E

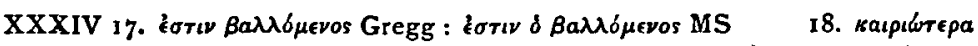
Robinson : kuptútepa MS 19. oúre MS . perhaps omit (Gregg) 22. äz6 MS :

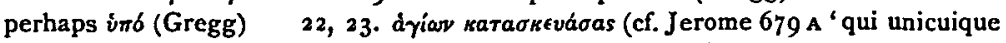

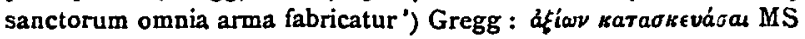




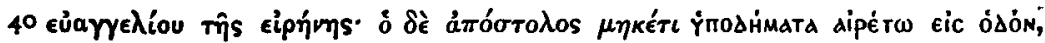

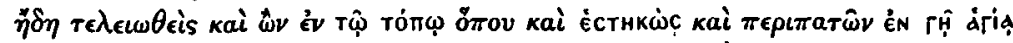

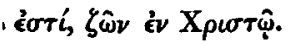

\section{$\S \mathrm{XXXV}$.}

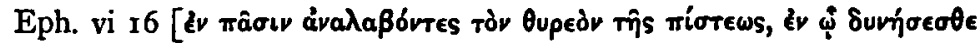

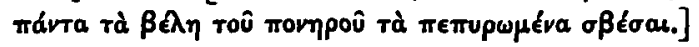

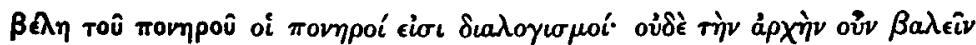

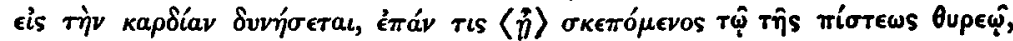

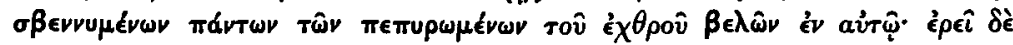

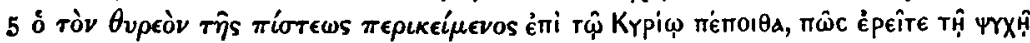

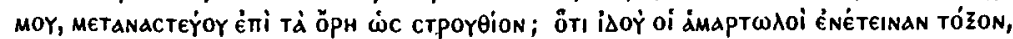

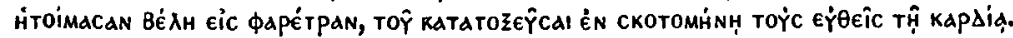

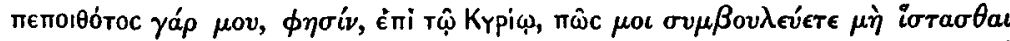

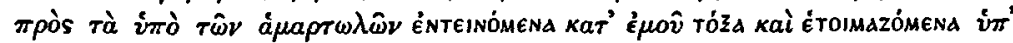

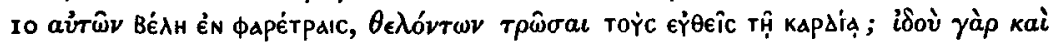

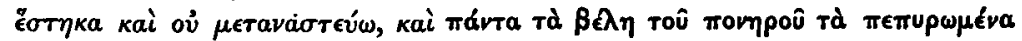
o̊ $\sigma o \nu$ ouี่ $\pi \omega \sigma \beta \epsilon \sigma \theta \dot{\eta} \sigma \epsilon \tau a$.

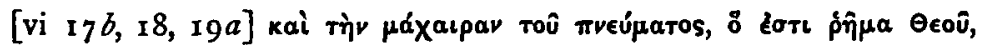

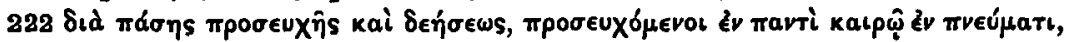

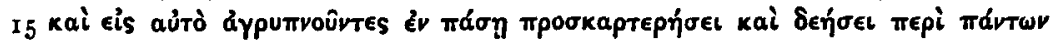

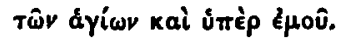

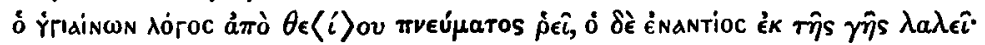

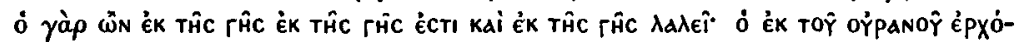

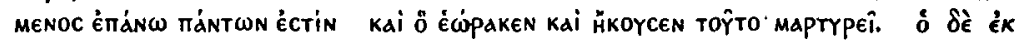

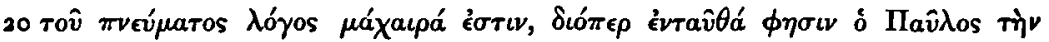

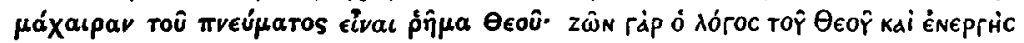

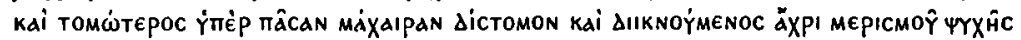

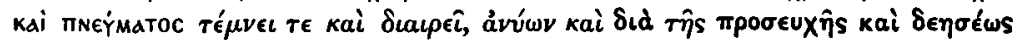

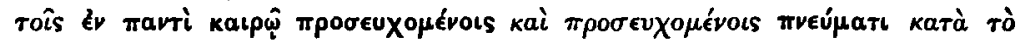

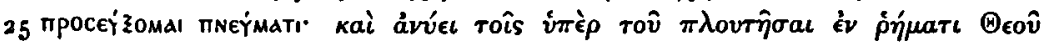

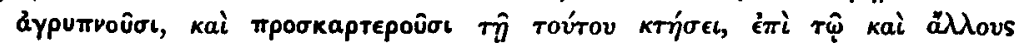

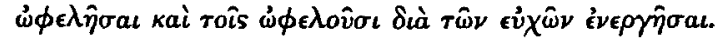

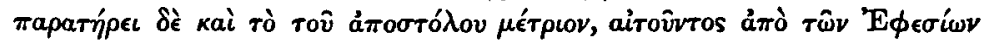

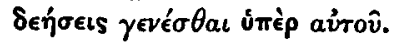

4\%. Matt. $\times 10$, Luc. ix $3, \times 4$ (cf. 2 Tim. i 13 )
18. Jo. iii $31,3^{2}$
$\mathrm{XXXV}$ 5. Ps. $\times(\mathrm{xi}) \mathrm{I}, 2$

21. Heb. iv 12
17. Tit. ii 8

25. I Cor, xiv I5

$\mathrm{XXXV}_{2-12}: 680 \mathrm{~B}-\mathrm{D} \quad 17-27: 681 \mathrm{~A} \mathrm{~B} \quad 28,29: 681 \mathrm{C}$

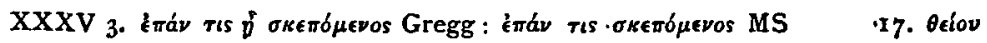
Gregg: $\theta \in \hat{O V}$ MS 24. Tois ' $\mathrm{v}$ (cf. Jerome $68 \mathrm{I} \cdot \mathrm{B}$ ' eorum qui in omni tempore') Turner : '́v rois MS (these are the last words of a page in the MS) 


\section{$\S$ XXXVI.}

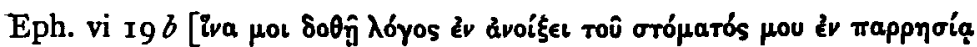

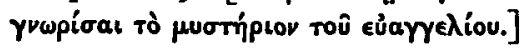

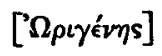

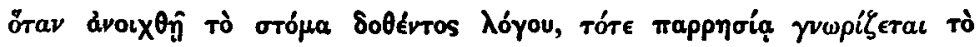

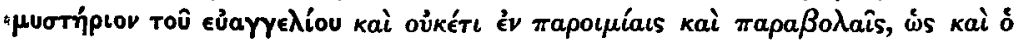

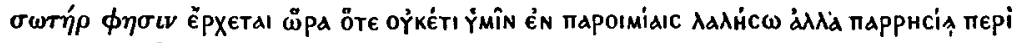

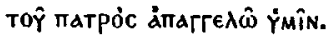

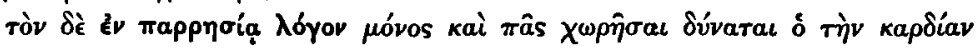

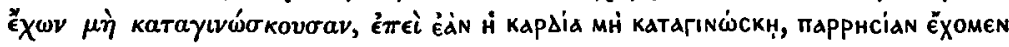

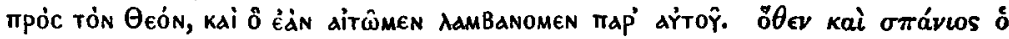

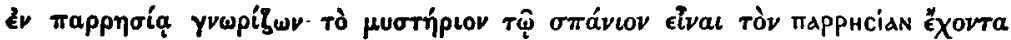

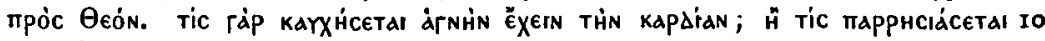

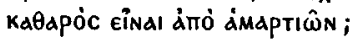

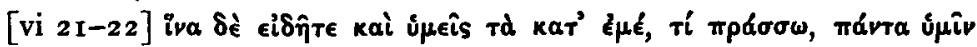

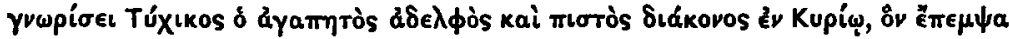

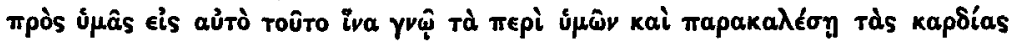
$\dot{u} \mu \hat{\omega} v$.

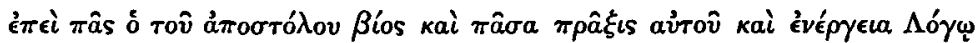

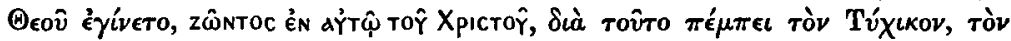

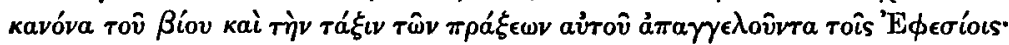

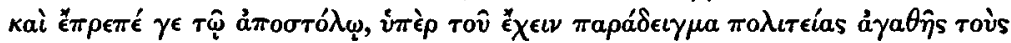

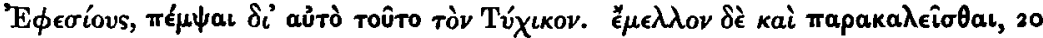

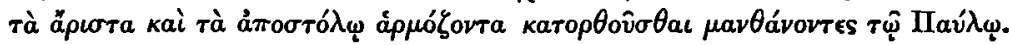

\section{$\S$ XXXVII.}

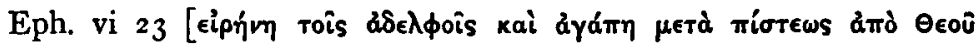

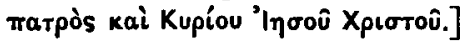

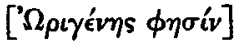

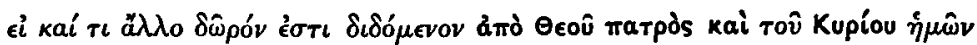

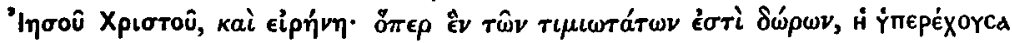

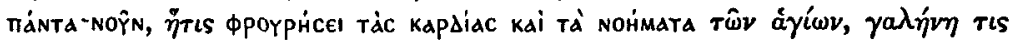

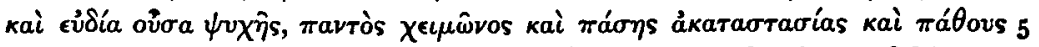

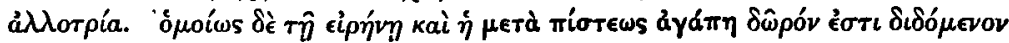

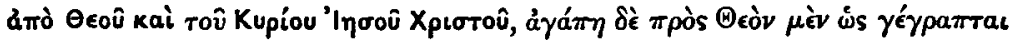

XXXVI 4. Jo. xvi 25 ๆ. I Jo. iii 21,22 (1o. Prov. $2 x 9$ 17. Gal. ii 20 XXXVII 3. Phil. iv 7

$$
\text { XXXVI 3-11: 681 E 682A I8-21:682 в 683A -XXXVII 2-10:683A B }
$$




\section{THE JOURNAL OF THEOLOGICAL STUDIES}

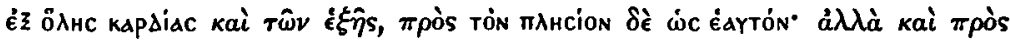

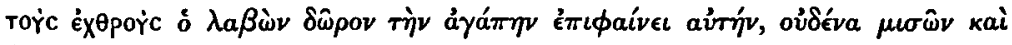
Io

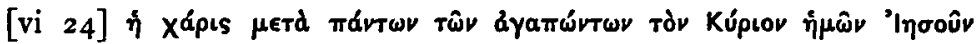

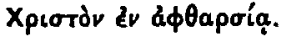

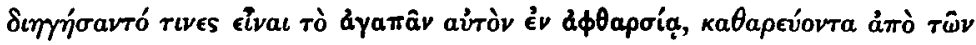

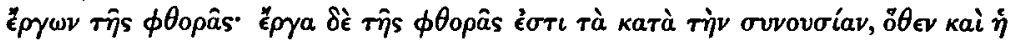

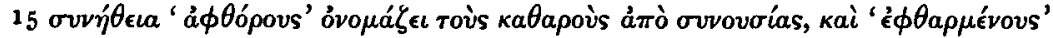

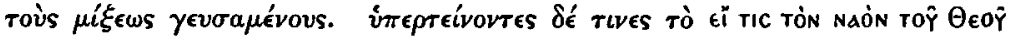

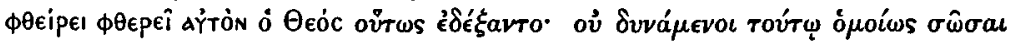

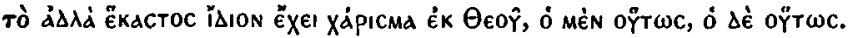

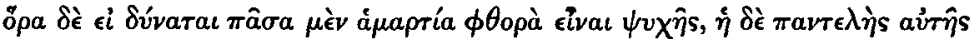

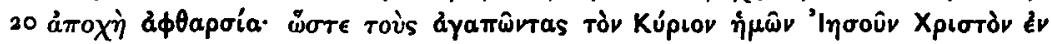

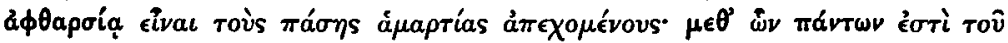
అ૯ô̂ Xápเs.

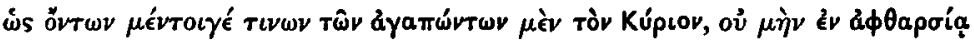

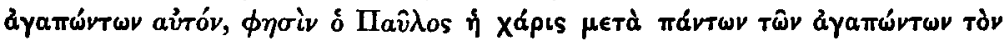

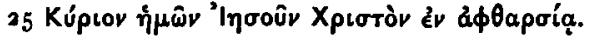

8. Marc. xii $3^{\circ}, 3^{1}$; Luc. $\times 27$ I Cor. iii 17 I8. I Cor. vii 7 .

$13-25: 68_{4} \mathrm{~A}-\mathrm{C}$.

XXXVII 17. roúrq : roura MS

J. A. F. GREGG ${ }^{1}$.

\section{A NEWLY DISCOVERED LEAF OF A FIFTH- CENTURY MS OF ST. CYPRIAN.}

By a curious coincidence, after I had written and put into type the account of the Turin and Milan fragments (Turin F IV 27 and Ambros. D 5 I 9 inf.) of a very early Bobbio MS of St. Cyprian which is published on pp. $582-584$ of the present number of the Journal, I learned that an additional leaf of the MS had come to light and was now in the possession of Hartwell Grissell, Esq., of Oxford, Cameriere d'Onore di Numero to his Holiness the Pope: and as this leaf was not known to Hartel and therefore not collated for his edition, I have thought it on all accounts desirable to take advantage of Mr. Grissell's kind permission and to transcribe it for the Journal.

1 It is hoped in a future number of the Jour wal to print an Index Graecitatis to the Commentary of Origen on the Epistle to the Ephesians. 